\title{
Dysfunction of exocytosis causes catecholamine hypersecretion in patient with pheochromocytoma
}

Sébastien Houy ${ }^{1 *}$, Laura Streit ${ }^{1 *}$, Ines Drissa ${ }^{2}$, Marion Rame ${ }^{1}$, Charles Decraene ${ }^{1,10}$, Sophie $\operatorname{Moog}^{1}$, Laurent Brunaud ${ }^{3}$, Joël Lanoix ${ }^{4}$, Rabie Chelbi ${ }^{1,7}$, Florence Bihain ${ }^{3}$, Stéphanie Lacomme $^{5}$, Sandra Lomazzi ${ }^{5}$, Michel Vix ${ }^{6}$, Didier Mutter ${ }^{6}$, Eustache Paramithiotis ${ }^{8}$, Christophe Dubessy ${ }^{2,9}$, Nicolas Vitale ${ }^{1}$, Stéphane Ory ${ }^{1 \#}$ and Stéphane Gasman ${ }^{1 \# ~}$

${ }^{1}$ Centre National de la Recherche Scientifique, Université de Strasbourg, Institut des Neurosciences Cellulaires et Intégratives, F-67000 Strasbourg, FRANCE.

${ }^{2}$ Normandie Université, UNIROUEN, INSERM, Laboratoire Différenciation et Communication Neuronale et Neuroendocrine, F-76000 Rouen, FRANCE.

${ }^{3}$ Département de Chirurgie Viscérale, Métabolique et Cancérologique (CVMC), Unité médicochirurgicale de chirurgie métabolique, endocrinienne et thyroïdienne (UMET), Unité médicochirurgicale de chirurgie de l'obésité (UMCO), Université de Lorraine, CHRU NANCY, Hôpital Brabois adultes, F-54511 Vandouvre-lès-Nancy, FRANCE.

${ }^{4}$ Institut de Recherche en Immunologie et en Cancérologie (IRIC), Université de Montréal, Montréal, QC H3C 3J7, Canada; Département de Médecine, Université de Montréal, Montréal, QC H3C 3J7, CANADA.

${ }^{5}$ Centre de Ressources Biologiques Lorrain, CHRU Nancy, Hôpitaux de Brabois, F-54511

Vandouvre-lès-Nancy, FRANCE.

${ }^{6}$ NHC Strasbourg, Service de Chirurgie Digestive et Endocrinienne des Hôpitaux

Universitaires de Strasbourg, Hôpital Civil, F-67000 Strasbourg, FRANCE.

${ }^{7}$ Inovarion, F-75005 Paris, FRANCE.

${ }^{8}$ CellCarta Biosciences, Inc., Montréal, Québec, CANADA H2X $3 Y 7$.

${ }^{9}$ Normandie Université, UNIROUEN, INSERM, PRIMACEN, F-76000 Rouen, FRANCE.

${ }^{10}$ Centre National de la Recherche Scientifique, Université de Strasbourg, Laboratoire de Neurosciences Cognitives et Adaptatives , F-67000 Strasbourg, FRANCE.

* S. Houy and L. Streit contributed equally to this paper \# S. Ory and S. Gasman contributed equally to this paper $\S$ Corresponding author: Stéphane Gasman, address as above. e-mail: gasman@inci-cnrs.unistra.fr

Running title: Secretion analysis in pheochromocytoma

Key words: calcium-regulated exocytosis, neuroendocrine secretion, pheochromocytoma, carbon fiber amperometry, mass spectrometry 


\begin{abstract}
Pheochromocytoma (Pheo) is a neuroendocrine tumor that develops from chromaffin cells of the adrenal medulla, and is responsible of an excess of catecholamines secretion leading to severe clinical symptoms such as hypertension, elevated stroke risk and various cardiovascular complications. Surprisingly, hypersecretory activity of Pheo has never been explored at the cellular and molecular levels from individual tumor cells. In the present study, we have combined catecholamine secretion measurement by carbon fiber amperometry on human tumor cells directly cultured from freshly resected Pheo, with the analysis by mass spectrometry of the exocytotic proteins differentially expressed between the tumor and the matched adjacent non-tumor tissue. Catecholamine secretion recordings from individual Pheo cells obtained from most patients reveal a higher number of exocytic events per cell associated with faster kinetic parameters. Accordingly, we unravel significant tumor-associated modifications in the expression of key proteins involved in different steps of the calcium-regulated exocytic pathway. Altogether, our findings indicate that dysfunction of the calcium-regulated exocytosis at the level of individual Pheo cell is a cause of the tumor-associated hypersecretion of catecholamines.
\end{abstract}




\section{Introduction}

Through the secretion of hormones and neuropeptides, the neuroendocrine system controls many vital functions such as metabolism, blood pressure, reproduction, growth and development, stress and eating behavior, to cite only a few. Neoplasms can derive from all kinds of hormone secreting cells giving rise to a neuroendocrine tumor (NET). NETs constitute a highly heterogeneous group of neoplasm, but share a common feature in that they are often associated with a deregulation of hormone secretion, mainly hypersecretion, which can induce symptoms and major clinical complications (Zandee et al, 2017). Therefore, the secretory pathways and their dysfunction appear as an important issue to be considered in NETs. However, the cellular and molecular mechanisms underlying hypersecretory activity of NETs remain poorly known.

In neuroendocrine cells, hormones and neuropeptides are stored in large dense core vesicles (secretory granules) and are secreted through calcium-regulated exocytosis, a process that has been intensively studied for decades (Anantharam \& Kreutzberger, 2019). It involves several tightly regulated trafficking steps including the recruitment of secretory granules to the cell periphery, their docking to exocytic sites of the plasma membrane, their priming and finally the fusion between the secretory granule membrane and the plasma membrane leading to the release of the intra-granular content (Burgoyne \& Morgan, 2003; Lang \& Jahn, 2008). Chromaffin cells of the adrenal medulla, which store and then secrete catecholamines into the blood stream, have been widely used by us and others as an experimental model to uncover the molecular mechanisms controlling calcium-regulated exocytosis (Bader et al, 2002; Gasman \& Vitale, 2017; Malacombe et al, 2006).

The NETs deriving from chromaffin cells of the adrenal medulla are called pheochromocytomas (Pheo) (Lenders et al, 2020). Most of the Pheos are responsible for catecholamine hypersecretion leading to clinical symptoms such as permanent or paroxysmal hypertension or to cardiovascular complications including myocarditis, Takotsubo syndrome and various forms of cardiomyopathies (Lenders et al., 2020; Pappachan et al, 2018; Pourian et al, 2015; Zhang et al, 2017). The reason for this excess of secretion is currently not known. Among the likely possibilities are an anarchic proliferation of secretory cells or an intensification of the secretory capacity at the single cell level. We therefore attempted to investigate the cellular mechanisms responsible for a possible specific secretion dysfunction in Pheo by performing carbon fiber amperometry on primary culture of human Pheo cells. This technique allows the precise measurement of individual exocytotic event dynamics in real time and in single cells (Fathali \& Cans, 2018; Mosharov \& Sulzer, 2005). Combined with the detection in human Pheo tissue of exocytotic protein expression changes by mass spectrometry, it allowed us to reveal upregulated exocytosis at the single cell level and to identify specific steps of the exocytotic process that are dysregulated in the tumor as well as potential actors of the molecular machinery triggering hypersecretion in Pheo. 
bioRxiv preprint doi: https://doi.org/10.1101/2021.11.02.466874; this version posted November 5, 2021. The copyright holder for this preprint (which was not certified by peer review) is the author/funder, who has granted bioRxiv a license to display the preprint in perpetuity. It is made available under aCC-BY-NC-ND 4.0 International license.

\section{Results}

\section{Technical workflow and overall patient characteristics}

This study includes two types of analyses (see technical workflow in Figure 1) performed on histologically confirmed Pheo samples from 27 distinct patients. On one side, we have analyzed the secretory activity of single tumor cells. To do so, freshly resected Pheos originating from 22 patients were placed in primary culture in order to perform real-time single cell catecholamine secretion measurement using carbon fiber amperometry (Figure 1A). On the other side, we have used quantitative mass spectrometry analysis to measure the relative differential expression of proteins involved in the exocytic pathway from 5 other Pheo tissues, which were compared to the matched patient non-tumor adrenal tissue. To conduct this proteomic analysis, two subcellular fractions enriched for exocytic proteins (the cytosolic fraction and a low-density membrane fraction containing plasma membrane, Golgi, endosomes and secretory vesicles) were isolated from the pairs of matched non-tumor and tumor frozen tissues (Figure 1B). Note that due to the low amount of human material, it is technically impossible to perform both amperometry and mass spectrometry experiments on the same samples.

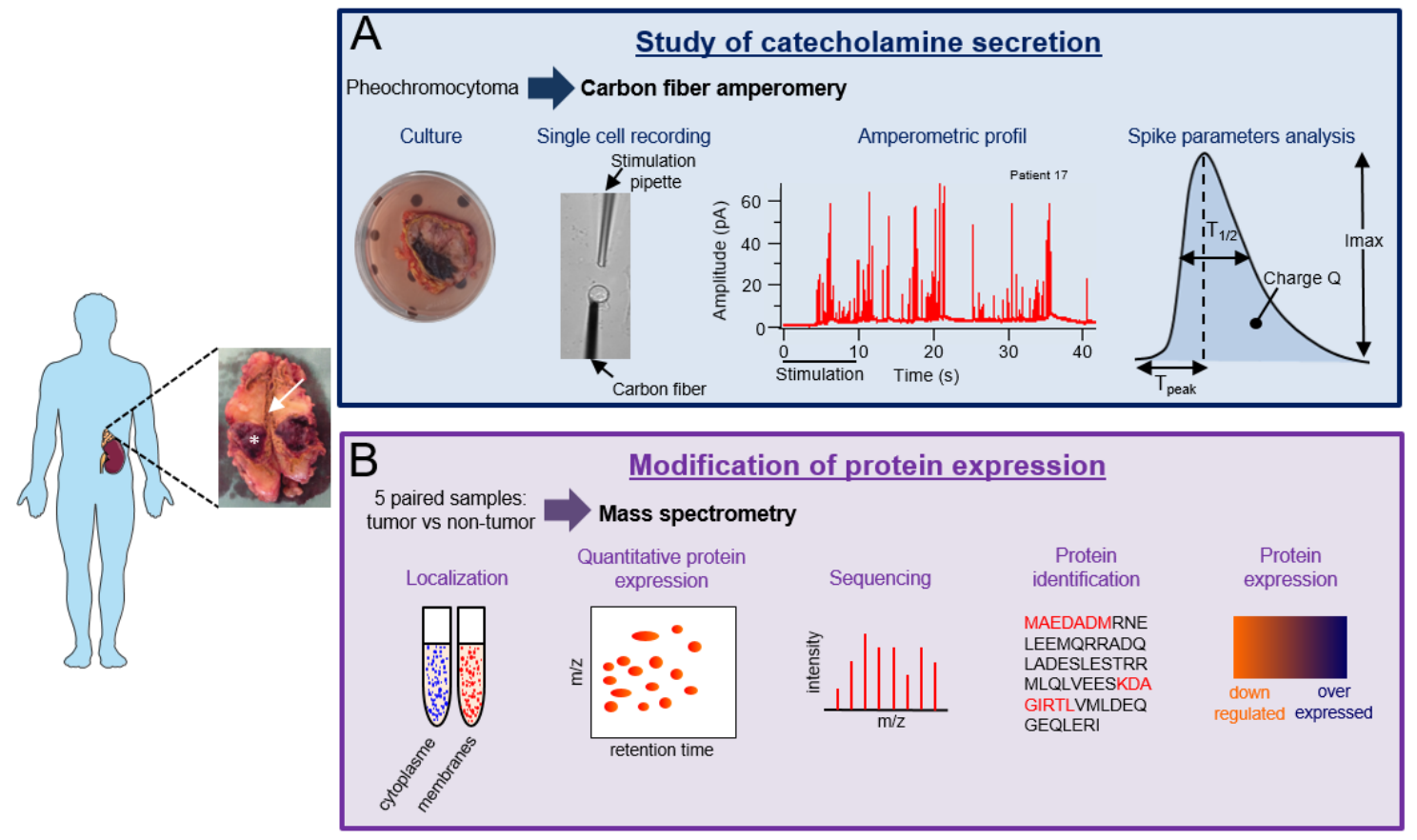

Figure 1: Technical workflow of catecholamine secretion measurement and comparative proteomic analysis of human Pheo. A resected adrenal gland, cut in half, from a patient with Pheo is shown (asterisk). The non-tumor tissue is shown by the arrow. (A) Description of the different steps of the catecholamine secretion measurement by carbon fiber amperometry from the primary cell culture of the tumor to the amperometric spike analysis. A representative amperometric trace of a Pheo cell is illustrated. The dark bar indicates when a $100 \mu \mathrm{M}$ nicotine solution was applied. The parameters of individual spike that were analyzed are indicated. (B) Complete protein profiling workflow of differential mass spectrometry analysis between Pheo tissue and matched non-tumor tissue. 
For patients included in the amperometric analysis, a slight predominance of male was found (59\%) with a mean age of $50.5 \pm 10$ years at diagnosis (Table 1). Sixteen patients $(73 \%)$ were diagnosed with hormonal-related symptoms whereas all of them presented abnormal hormonal secretion (100\%) including adrenergic or noradrenergic phenotype in $13(59 \%)$ and $9(41 \%)$ cases, respectively. Seven patients $(46 \%)$ out of 16 tested were diagnosed with a genetic predisposition ( 4 NF1, 1 RET, $1 S D H B$ and $1 S D H D$ ). The mean tumor size was $4.5 \mathrm{~cm}$ (range $1.7-8 \mathrm{~cm}$ ). Other biological and clinical characteristics are detailed in Table 1.

Biological and clinical characteristics of the 5 patients included for the proteomic analysis are detailed in Table 2 . With a mean age of $58 \pm 8$ years, these 5 patients had hormonal-related symptoms at diagnosis, four of which were classified as adrenergic phenotype and one as noradrenergic phenotype. None of the patients had germline mutation (out of 3 patients tested). The mean tumor size was $5.3 \mathrm{~cm}$ (range $3-8 \mathrm{~cm}$ ). Individual characteristics of the 27 patients can be found in Supplementary Table 1.

Table 1: Biological and clinical characteristics of the 22 patients from which Pheo were used for amperometric analysis.

\begin{tabular}{|c|c|}
\hline \multicolumn{2}{|l|}{ Characteristics, $n$ available } \\
\hline Age at diagnosis (mean $\pm \mathrm{SD}$, years), $n=22$ & $50.5 \pm 10$ \\
\hline Males $(\%), n=22$ & $13(59 \%)$ \\
\hline $\begin{aligned} \text { Symptoms at diagnosis: } & n=22 \\
- & \text { Tumoral-related symptoms }(\%) \\
- & \text { Hormonal-related symptoms }(\%)\end{aligned}$ & $\begin{array}{c}\mathbf{4}(18 \%) \\
\mathbf{1 6}(73 \%)\end{array}$ \\
\hline 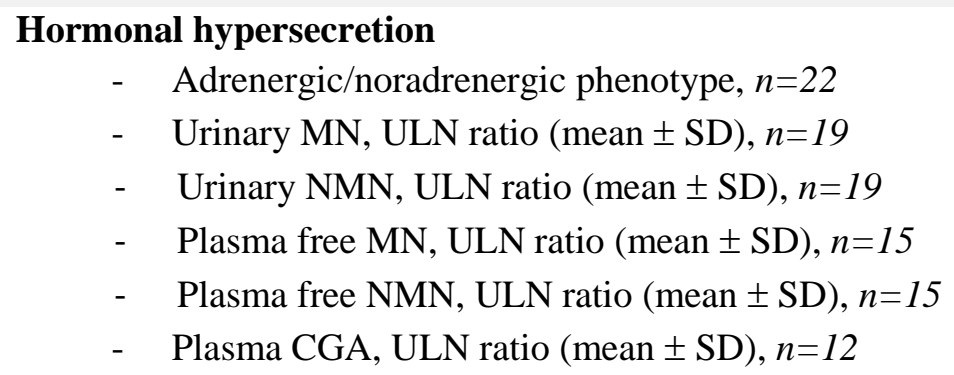 & $\begin{array}{c}13 / 9 \\
9.3 \pm 14 \\
7.7 \pm 5.6 \\
4.5 \pm 5.0 \\
6.2 \pm 6.1 \\
3.4 \pm 2.6\end{array}$ \\
\hline $\begin{array}{l}\text { Pathology: } \\
\begin{aligned}- & \text { Tumor size (mean + range) }, n=21 \\
- & \text { Ki-67 (mean + range), } n=12 \\
- & \text { PASS score (mean + range), } n=22\end{aligned}\end{array}$ & $\begin{array}{l}4.5(1.7-8) \\
2.1(1-5) \\
1.9(0-6)\end{array}$ \\
\hline $\begin{aligned} \text { Genetics: } & n=16 \\
- & \text { No germline mutation }(\%) \\
- & N F 1 \\
- & R E T \\
- & S D H B \\
- & S D H D\end{aligned}$ & $\begin{array}{c}\mathbf{9}(56.25 \%) \\
\mathbf{4}(25 \%) \\
\mathbf{1}(6.25 \%) \\
\mathbf{1}(6.25 \%) \\
\mathbf{1}(6.25 \%)\end{array}$ \\
\hline $\begin{array}{l}\text { MN: metanephrine, NMN: normetanephrine, ULN: upper lim } \\
\text { Pheochromocytoma of the Adrenal Gland Scaled Score, } \\
\text { Rearranged during transfection, SDHB: Succinate dehydroge } \\
\text { D. }\end{array}$ & $\begin{array}{l}\text { CGA: chr } \\
\text { trofibrome } \\
\text { HD: Succ }\end{array}$ \\
\hline
\end{tabular}


Table 2: Biological and clinical characteristics of the 5 patients from which Pheo were used for proteomic analysis

\begin{tabular}{|c|c|}
\hline Characteristics, $n$ available & \\
\hline Age at diagnosis (mean $\pm \mathrm{SD}$, years), $n=5$ & $58 \pm 8$ \\
\hline Males (\%), $n=5$ & $2(40 \%)$ \\
\hline $\begin{aligned} \text { Symptoms at diagnosis: } & n=5 \\
- & \text { Tumoral-related symptoms }(\%) \\
- & \text { Hormonal-related symptoms }(\%)\end{aligned}$ & $\begin{array}{c}\mathbf{1}(20 \%) \\
\mathbf{5}(100 \%)\end{array}$ \\
\hline 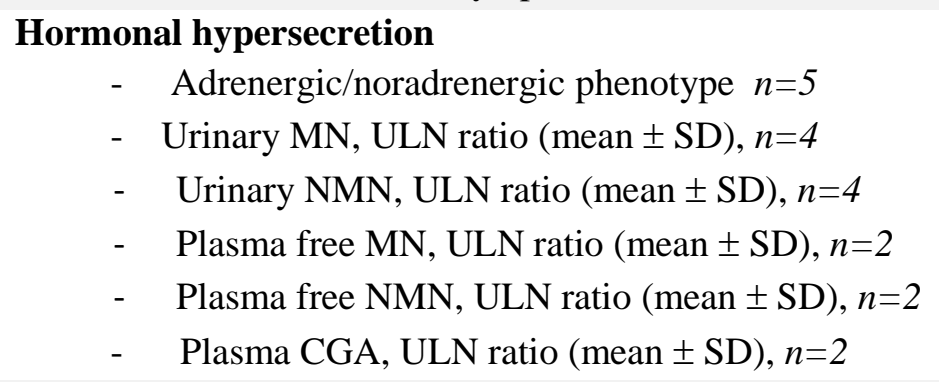 & $\begin{array}{c}4 / 1 \\
3.7 \pm 4.2 \\
6.8 \pm 8 \\
3.0 \pm 2.8 \\
3.0 \pm 2.8 \\
4.7 \pm 2.9\end{array}$ \\
\hline $\begin{array}{l}\text { Pathology: } \\
\begin{aligned} \text { - } & \text { Tumor size, cm (mean + range), } n=5 \\
\text { - } & \text { Ki- } 67, \%(\text { mean }+ \text { range }), n=3 \\
\text { - } & \text { PASS score (mean + range }), n=3\end{aligned}\end{array}$ & $\begin{array}{c}\mathbf{5 . 3}(3-8) \\
\mathbf{3 . 3}(1-7) \\
\mathbf{3}(0-9)\end{array}$ \\
\hline $\begin{aligned} \text { Genetics: } & n=3 \\
\text { - } & \text { No germline mutation }(\%)\end{aligned}$ & $3(100 \%)$ \\
\hline
\end{tabular}

Analysis of catecholamine secretion in human pheochromocytoma by carbon fiber amperometry

A representative amperometric trace recorded from a human Pheo cell is illustrated in Figure 1A. Each individual spike represents a single granule fusion event and is composed of a rapid rise of the electrode current corresponding to the oxidation of catecholamines quickly released at high concentration through the fusion pore as it dilates. The spike rise is then followed by a slower decay representing a decreased of the catecholamine flux through the pore as the granule empties. In addition to the quantification of number of events per cell, the analysis of individual amperometric spikes provides valuable dynamic information on the exocytic process. Hence, the surface area or quantal size (Q) is proportional to the amount of catecholamines released per event, the spike amplitude value (Imax) reflects the maximal flux of catecholamines, whereas the half-width $\left(T_{1 / 2}\right)$, and the time to peak $\left(T_{p e a k}\right)$ reflect the duration of the exocytotic event and the kinetics of the fusion pore expansion, respectively (Figure 1A).

Primary culture of human Pheo cells is rather efficient as most attempts were successful. However, culturing non-tumor chromaffin cells taken outside the tumor zone sample appeared 
trickier and failed most of the time for unidentified reasons. Nevertheless, we were able to obtain 4 different cultures of non-tumor cells that could be used for amperometric recordings. Therefore, we have compared the distribution of the amperometric parameters of each of the 22 patients individually with the mean values calculated from these 4 non-tumor samples. All the amperometric parameters are detailed in Table 3. The major change concerns the total number of spikes. Indeed, among the 22 patients, $16(73 \%)$ exhibit a significant increase of the number of spikes (11 patients with an increase up to 2 fold and 5 patients with an increase above 2 and up to 3.4 fold; Figure 2). Hence these data suggest that one of the main causes of tumorassociated catecholamine hypersecretion could be an increase of the number of exocytic events.

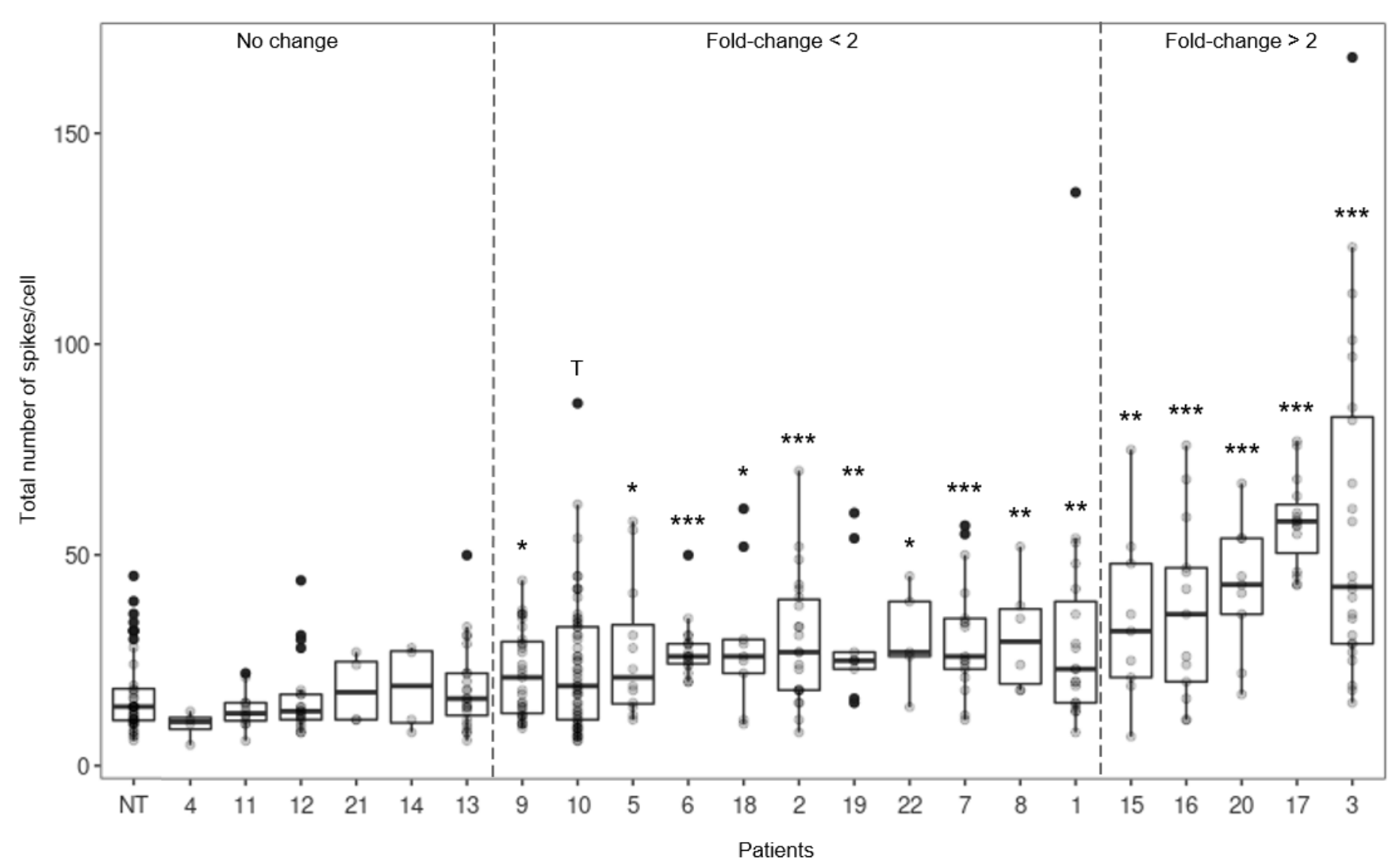

Figure 2: Analysis of catecholamine secretion events in Pheo cells from each patient by carbon fiber amperometry. Box-and-whisker diagrams illustrating the distribution of the number of amperometric spikes per cell for non-tumor cells (NT) and for cells from each patient with Pheo. Patients are classified according to the increasing effect of the number of spikes compared to non-tumor cells: no significant change, fold-change $<2$ and fold-change $>2 ;{ }^{T} p=0.05,{ }^{*} p<0.05, * * p<0.01 ; * * * p<0.001$ compared to the mean of non-tumor tissue; non-paired Wilcoxon test. 
bioRxiv preprint doi: https://doi.org/10.1101/2021.11.02.466874; this version posted November 5,2021 . The copyright holder for this preprint (which was not certified by peer review) is the author/funder, who has granted bioRxiv a license to display the preprint in perpetuity. It is made available under aCC-BY-NC-ND 4.0 International license.

Table 3: Characteristics of amperometric spikes from 22 Pheos and 4 non-tumor tissues.

\begin{tabular}{|c|c|c|c|c|c|c|c|}
\hline Identification & $\begin{array}{l}\text { Number of } \\
\text { cells }\end{array}$ & $\begin{array}{l}\text { Total number } \\
\text { of spikes }\end{array}$ & $\begin{array}{l}\text { Total number of } \\
\text { spikes/cell }\end{array}$ & $\begin{array}{l}\text { Number of } \\
\text { spikes }\end{array}$ & $\operatorname{Imax}(\mathrm{pA})$ & Charge (pC) & $\mathrm{T}_{1 / 2}(\mathrm{~ms})$ \\
\hline Non-tumor 1 & 19 & 224 & $11.79 \pm 0.67$ & 146 & $41.56 \pm 2.23$ & $2.22 \pm 0.13$ & $51.90 \pm 1.14$ \\
\hline Non-tumor 2 & 11 & 164 & $14.91 \pm 2.05$ & 126 & $10.92 \pm 0.81$ & $0.92 \pm 0.10$ & $68.41 \pm 3.41$ \\
\hline Non-tumor 3 & 8 & 144 & $18.00 \pm 3.44$ & 102 & $18.77 \pm 2.35$ & $0.73 \pm 0.20$ & $30.76 \pm 3.94$ \\
\hline Non-tumor 4 & 6 & 214 & $35.67 \pm 2.17$ & 112 & $15.51 \pm 1.65$ & $0.97 \pm 0.12$ & $56.13 \pm 4.26$ \\
\hline Patient 1 & 19 & 609 & $32.05 \pm 6.61^{\star *}$ & 4669 & $21.34 \pm 2.16$ & $0.90 \pm 0.10$ * & $38.97 \pm 2.70^{* * *}$ \\
\hline Patient 2 & 22 & 653 & $29.68 \pm 3.26^{\star \star \star \star}$ & 518 & 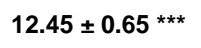 & $0.71 \pm 0.04^{\star \star \star}$ & $52.11 \pm 1.69$ \\
\hline Patient 3 & 24 & 1388 & $57.83 \pm 8.01$ *** & 1032 & $27.85 \pm 2.91$ & $1.79 \pm 0.16$ & $61.69 \pm 2.74$ * \\
\hline Patient 4 & 4 & 39 & $9.75 \pm 1.70$ & 38 & $13.08 \pm 3.20$ & $0.71 \pm 0.26$ & $44.90 \pm 8.53$ \\
\hline Patient 5 & 12 & 326 & $27.17 \pm 4.74$ * & 240 & $13.82 \pm 0.92$ * & $1.30 \pm 0.11$ & $80.38 \pm 5.65^{* \star \star}$ \\
\hline Patient 6 & 18 & 499 & $27.72 \pm 1.60^{\star \star \star}$ & 320 & $45.78 \pm 2.00^{\star \star \star}$ & $2.33 \pm 0.10^{\star \star \star}$ & $48.34 \pm 0.76$ * \\
\hline Patient 7 & 17 & 524 & $30.82 \pm 3.32$ *** & 408 & $11.04 \pm 0.58$ ** & $0.96 \pm 0.07$ & $69.70 \pm 3.27^{\star *}$ \\
\hline Patient 8 & 6 & 185 & $30.83 \pm 5.46$ ** & 163 & $30.99 \pm 4.50$ & $2.00 \pm 0.29$ & $65.30 \pm 6.54$ \\
\hline Patient 9 & 31 & 682 & $22.00 \pm 1.85$ * & 416 & $40.28 \pm 1.61^{\star \star *}$ & $1.71 \pm 0.08$ & $40.29 \pm 1.13^{* \star *}$ \\
\hline Patient 10 & 59 & 1382 & $23.42 \pm 2.04^{\top}$ & 1231 & $21.26 \pm 1.28$ & $1.25 \pm 0.08$ & $52.81 \pm 2.19$ \\
\hline Patient 11 & 12 & 161 & $13.42 \pm 1.31$ & 130 & $17.39 \pm 2.35$ & $0.85 \pm 0.11$ * & $42.54 \pm 2.76$ * \\
\hline Patient 12 & 21 & 345 & $16.43 \pm 2.01$ & 292 & $20.17 \pm 2.71$ & $0.81 \pm 0.10^{* *}$ & $35.45 \pm 1.20$ *** \\
\hline Patient 13 & 23 & 428 & $18.61 \pm 2.16$ & 353 & $11.28 \pm 0.81^{\star \star \star}$ & $0.68 \pm 0.05^{* \star *}$ & $52.01 \pm 2.47$ \\
\hline Patient 14 & 4 & 74 & $18.50 \pm 5.24$ & 59 & $27.09 \pm 5.68$ & $1.01 \pm 0.14$ & $35.08 \pm 1.80$ * \\
\hline Patient 15 & 9 & 315 & $35.00 \pm 6.88$ ** & 187 & $13.91 \pm 1.93$ * & $0.49 \pm 0.08^{\star \star \star}$ & $30.03 \pm 1.99$ *** \\
\hline Patient 16 & 12 & 482 & $37.08 \pm 5.96$ *** & 334 & $21.58 \pm 2.30$ & $0.93 \pm 0.14$ * & $37.39 \pm 2.83^{* \star}$ \\
\hline Patient 17 & 15 & 866 & $57.73 \pm 2.76^{\star \star \star \star}$ & 400 & $23.72 \pm 1.15$ & $1.04 \pm 0.06$ & 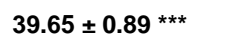 \\
\hline Patient 18 & 9 & 266 & $29.56 \pm 5.66$ * & 140 & $19.18 \pm 1.75$ & $1.72 \pm 0.24$ & $79.57 \pm 6.60$ *** \\
\hline Patient 19 & 9 & 270 & $30.00 \pm 5.31$ ** & 197 & $13.96 \pm 1.03$ * & $0.55 \pm 0.04^{* * *}$ & $35.21 \pm 1.19$ *** \\
\hline Patient 20 & 9 & 379 & $42.11 \pm 5.25^{\star \star \star}$ & 276 & $15.84 \pm 2.19$ & $0.60 \pm 0.10^{\star \star *}$ & $33.53 \pm 2.29$ *** \\
\hline Patient 21 & 4 & 73 & $18.25 \pm 4.23$ & 59 & $16.29 \pm 5.83$ & $0.74 \pm 0.19$ & $45.37 \pm 2.51$ \\
\hline \multirow[t]{2}{*}{ Patient 22} & 5 & 151 & $30.20 \pm 5.42$ * & 82 & $25.13 \pm 5.40$ & $1.72 \pm 0.30$ & $65.82 \pm 6.82$ \\
\hline & $\begin{array}{l}\text { Amperometri } \\
\text { Cells were sti } \\
\text { spikes per ce } \\
\text { mean } \pm \text { SEM } \\
* p<0.05 \text {, ** } \\
\text { test. }\end{array}$ & $\begin{array}{l}\text { crecordings } \\
\text { mulated with } \\
\text { Bl and the di } \\
\text { Bold values } \\
p<0.01 ; * *\end{array}$ & $\begin{array}{l}\text { were performe } \\
100 \mu M \text { of nico } \\
\text { ferent amperor } \\
\text { are considere } \\
p<0.001 \mathrm{com}\end{array}$ & $\begin{array}{l}\text { on primar } \\
\text { ne for } 10 \mathrm{~s} \\
\text { etric spike } \\
\text { significant } \\
\text { ared to the }\end{array}$ & $\begin{array}{l}\text { ulture of hun } \\
\text { he number of } \\
\text { arameters ar } \\
\text { different fron } \\
\text { lean of non-t }\end{array}$ & $\begin{array}{l}\text { Pheo cells } \\
\text { ls, the numbe } \\
\text { ndicated. Re } \\
\text { ie control co } \\
\text { or tissue; no }\end{array}$ & $\begin{array}{l}\text { on-tumor cells. } \\
\text { f amperometric } \\
\text { ts represent the } \\
\text { itions; }{ }^{T} p=0.05 \text {, } \\
\text { aired Wilcoxon }\end{array}$ \\
\hline
\end{tabular}


To better understand which parameters are mostly driving the secretory tumor profiles and to sort out potential patient clusters, we performed a principal component analysis (PCA) using the amperometric data obtained from the 22 tumor cell cultures (Figure 3). As shown in Figure $3 \mathrm{~A}$, the 3 first principal components explain all the data variations $(97.3 \%)$. The correlation matrix indicated that the main amperometric parameters explaining the variation of the data within the 2 first dimensions are the charge and the $T_{\text {peak }}$ and to a lesser extend the $T_{1 / 2}$, parameters that are all correlated as shown by the variable projection analysis. The number of spikes per cell are less correlated and largely contributes to the third PCA dimension. Thus, it is interesting to note that the distribution of the patient samples plotted according to the first and the third component reveals a clear separation between populations with and without exocytic event increase as compared to non-tumor cells (Figure 3B). The distribution of the patient samples plotted according to the two first components forms one major cluster including most of the patients for which the two kinetic parameters, $T_{1 / 2}$ and $T_{\text {peak }}$, are significantly decreased (Figure 3C). Indeed, 14 (64\%) patient's tumor cell cultures presented a significant reduction of the $T_{1 / 2}$ and/or $T_{\text {peak }}$, often accompanied (9 patients) with a reduction of the quantal size (Charge Q; Figure 4A, B and Table 3). This type of amperometric profile corresponds to exocytic events occurring with a faster kinetics compared to normal cells. Interestingly, among these 14 patient samples, 10 displayed a concomitant increase of spikes per cells (Figure 2). Only 4 patient's cultured cells (18\%) displayed, on contrary, a significant increase of their $T_{1 / 2}$ leading, for two patients, to a reduce spike amplitude (Imax, patients 5 and 7, Figure 4C and Table 3) and accordingly to a slower release kinetics. Finally, 4 patient's cultured cells (18\%) do not show significant changes in charge, $T_{1 / 2}$ or $\mathrm{T}_{\text {peak }}$ indicating that the kinetic of the secretion in unaffected (Figure 4D). Altogether, our analysis of the amperometric recordings indicate that catecholamine secretion in tumor cells from patients with Pheo often involves a high number and fast secretory events, which most likely contribute to the tumor-associated hypersecretion. 


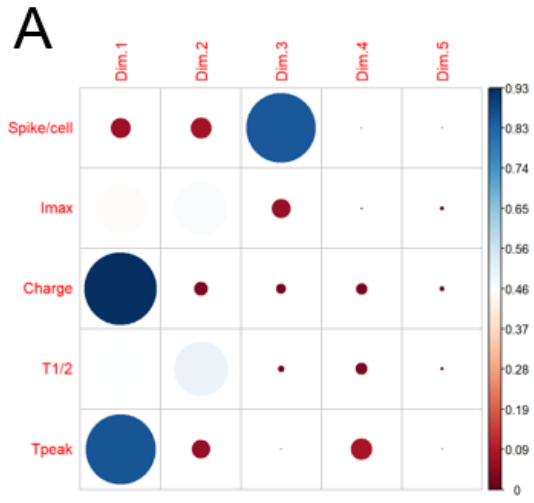

B spikelcell variations

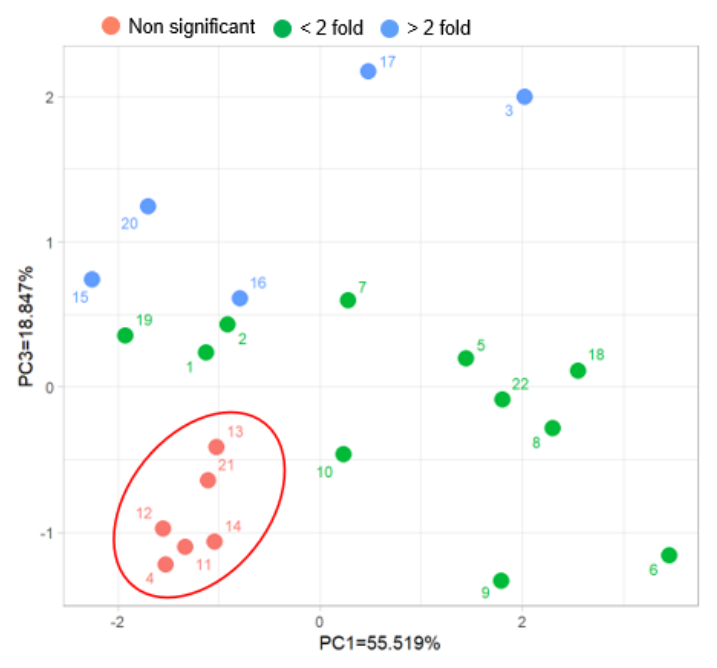

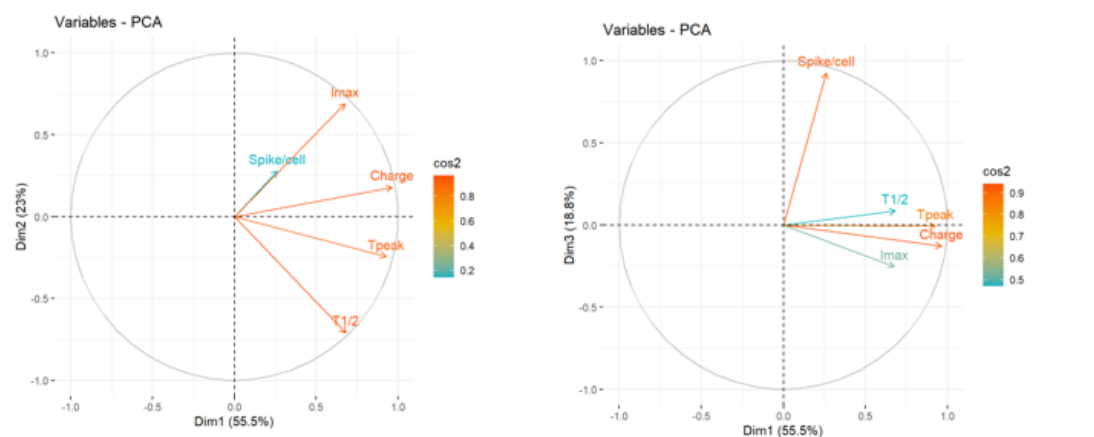

C Spike parameters variations

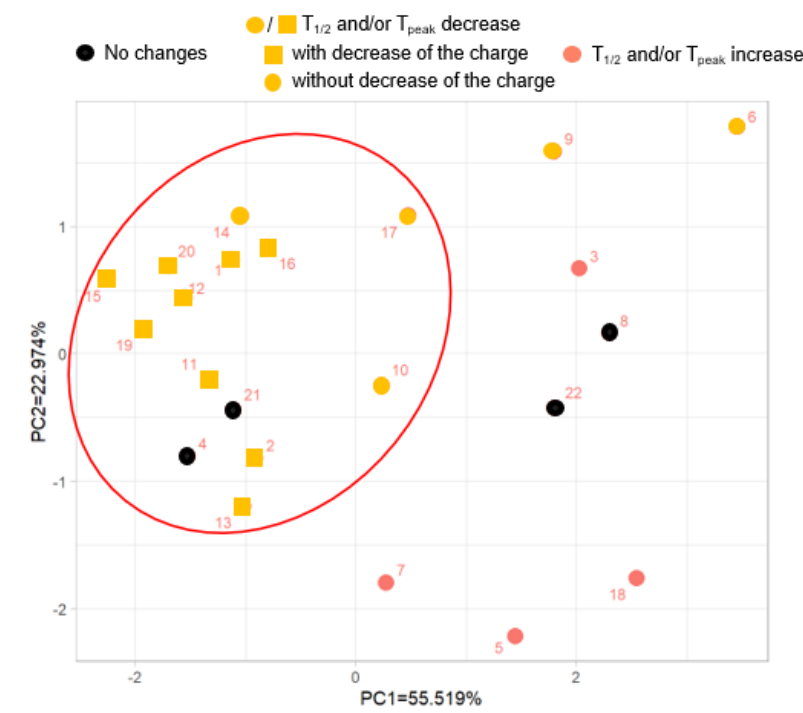

Figure 3: Principal component analysis (PCA) of amperometric spike parameters corresponding to catecholamine secretion recording on tumor cells cultured from 22 patients with Pheo. Number of spikes/cell and spike parameters (Imax, Charge, $T_{1 / 2}$ and $T_{\text {peak }}$ ) were subjected to PCA. (A) Correlation matrix and variable factor maps along the PCA dimensions. The first, second and third dimension (Dim) of principal components explain 55.5\%, 23.0\% and $18.8 \%$ of the data variations, respectively. The spike parameters Charge and $T_{\text {peak }}$ largely contribute to Dim 1 whereas $T_{1 / 2}$ and number of spikes per cell contribute to Dim 2 and 3, respectively. PCA variable vector map showing the projection of Imax, Charge, $T_{\text {peak }}$ and $T_{1 / 2}$ on Dim2 (right) and Dim3 (left). The projection of each variable vector gives an indication of the relation of these variables to $T_{\text {peak }}$ and Charge (Dim1) or spikes/cell (Dim3) (B-C) The two-dimensional representation of $P C 1$ and $P C 3(B)$ allowed to separate patients according to the significant variation of the number of spikes recorded per cell (red circle $=$ no changes; green circles $=$ fold change $<2$; blue circles $=$ fold change $>2$ ). The two-dimensional representation of PC1 and $P C 2(C)$ revealed a large cluster of patients for which $T_{1 / 2}$ and/or $T_{\text {peak }}$ decreased (yellow squares and circles). 
bioRxiv preprint doi: https://doi.org/10.1101/2021.11.02.466874; this version posted November 5, 2021. The copyright holder for this preprint (which was not certified by peer review) is the author/funder, who has granted bioRxiv a license to display the preprint in perpetuity. It is made available under aCC-BY-NC-ND 4.0 International license.
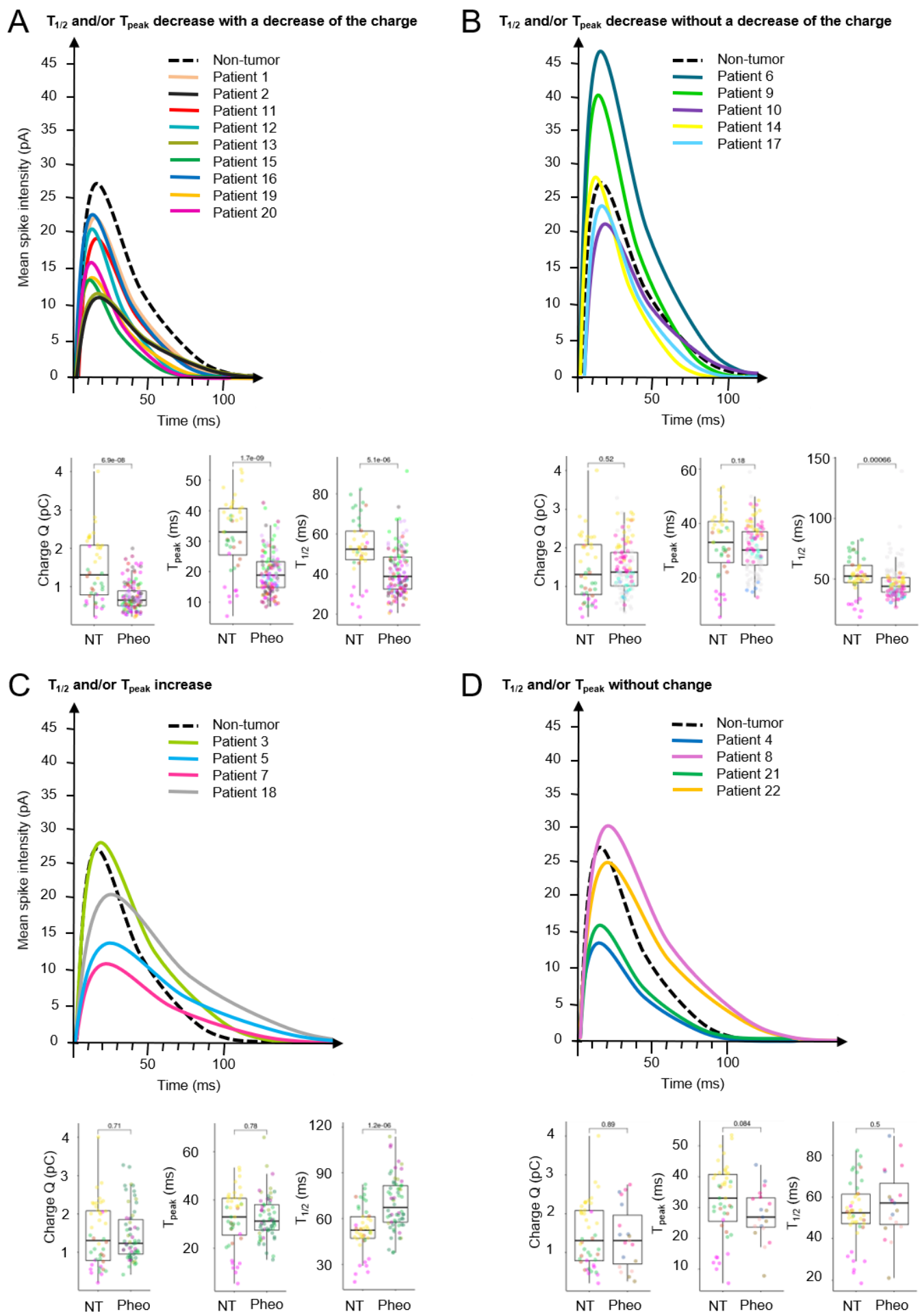

Figure 4: Analysis of amperometric spike parameters in Pheo cells from each patient. Superimposition of the averaged spike obtained for cells of each patient and distribution of the values corresponding to the spike charge $(Q)$, the spike rise time $\left(T_{p e a k}\right)$ and the spike half-width $T_{1 / 2}$ are shown for the 4 different populations of patients: decrease of $T_{1 / 2}$ and/or $T_{\text {peak }}$ with lower charge (A), decrease of $T_{1 / 2}$ and/or $T_{\text {peak }}$ without lower charge $(B)$, increase of $T_{1 / 2}$ and/or $T_{\text {peak }}(C)$ and no significant changes of $T_{1 / 2}$ and/or $T_{p e a k}(D)$. Box- and-whisker diagrams illustrate the distribution of each variable values pooled from all the patients belonging to the indicated secretory profile. $P$ values are indicated and patients are color coded. All the average amperometric data are detailed in Table 3. 
bioRxiv preprint doi: https://doi.org/10.1101/2021.11.02.466874: this version posted November 5,2021 . The copyright holder for this preprint (which was not certified by peer review) is the author/funder, who has granted bioRxiv a license to display the preprint in perpetuity. It is made available under aCC-BY-NC-ND 4.0 International license.

\section{Differential protein expression of the exocytic machinery in human pheochromocytoma}

Since catecholamine release is altered in Pheo, we asked whether proteins of the core machinery of secretory granule exocytic process could be deregulated. To do so, we performed a mass spectrometry analysis comparing 5 pairs of human Pheo with their respective matched adjacent non-tumor tissue. To increase detection and sensitivity, we conducted the proteomic analysis on purified subcellular fractions in place of total homogenate. Two main subcellular fractions were isolated from each tissue sample, a membrane fraction enriched for organelles and vesicles derived from the exocytic pathway and a fraction enriched in cytosolic proteins. From our proteomic data set, we selected proteins from the regulated exocytosis (\#BPGO:0045055) and secretory granule (\#CCGO:0030141) GO terms and focused on proteins significantly up or downregulated in the tumor by comparison with the corresponding non-tumor tissue, with fold change values greater than or equal to 2 . In these conditions, we identified 166 deregulated proteins: 62 proteins from the cytosolic fraction, 54 from the membrane-enriched fraction and 50 common to both fractions (Figure 5A). Supplementary Table 2 details the median value of the relative expression changes of the 5 pairs of Pheo samples for all these 166 selected proteins associated with their known function. The volcano plot in Figure 5B shows the relationship between the p-values and the fold change in expression. The unsupervised hierarchical clustering of all differentially expressed proteins in row according to the paired samples in columns, is presented in Figure 5C for the corresponding cellular compartment. Note that the expression of proteins found in common in the membranous and the cytosolic fractions varies in the same direction (Supplementary Figure 1). This specific dataset of proteins corresponding to the proteins involved in the machinery of secretory granule exocytotic process clearly differentiate, by their modulation of expressions, the Pheo samples from the non-tumor samples. The functions of the deregulated proteins linked to secretory granule exocytosis include mainly: secretory granule organization and biogenesis, hormone processing, vesicular trafficking, docking, priming, membrane fusion, actin cytoskeleton organization, and small GTPases (Supplementary Table 2 and Figure 5D). Hence, we observed that numerous secretory granules cargos, as well as different proteins involved in the control of the frequency and the dynamic of the exocytic events are up-regulated. 
bioRxiv preprint doi: https://doi.org/10.1101/2021.11.02 466874 this version posted November 5,2021 . The copyright holder for this preprint (which was not certified by peer review) is the author/funder, who has granted bioRxiv a license to display the preprint in perpetuity. It is made available under aCC-BY-NC-ND 4.0 International license.

A
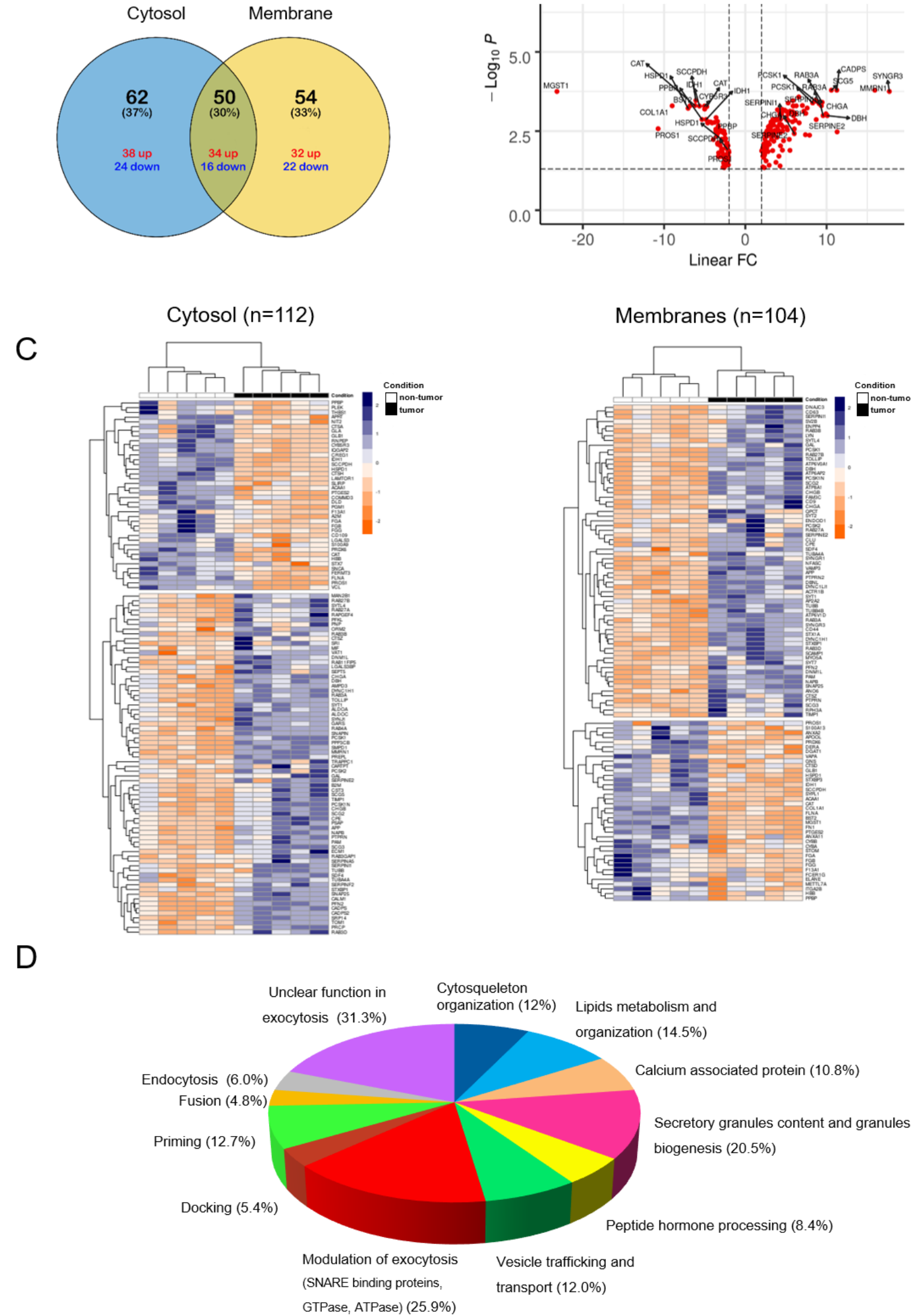
Figure 5: Identification of differentially expressed proteins involved in the exocytotic pathway in human Pheo tissue. (A) Venn diagram showing the distribution of the differentially expressed proteins in fractions enriched in cytosolic and membrane proteins. Colors indicate up-(red) or down-(blue) regulation. (B) Volcano plot of all differentially expressed proteins between Pheo and non-tumor samples. (C) Two-way hierarchical clustering of paired samples from each patient (non-tumor in white and tumor in black) in column according to the validated cytosolic (left) and membranous (right) proteins of the data set in row. Protein expression values were z-score normalized prior to clustering using the complete-linkage method together with the Euclidean distance. Each row represents a differentially expressed protein and each column, a patient according to the tissue type. The color scale illustrates the relative level of protein expression: red, higher expression; blue, lower expression. (D) Functional enrichment analysis of identified proteins. Each differentially expressed protein selected for their potential role in calcium-regulated exocytosis (Table 4) has been classified in one or several indicated biological functions.

To further assess the relevance of our data, we have compared our proteome dataset to a published gene expression analysis of 60 Pheo and 6 normal adrenal medulla tissues ((LopezJimenez et al, 2010) https://www.ncbi.nlm.nih.gov/geo/query/acc.cgi?acc=GSE19422). Using this analysis, we have extracted 170 genes that belong at least to one of the 2 GO terms used in the proteomic analysis (regulated exocytosis and secretory granules) and that are significantly differentially expressed by at least two-fold between Pheo and normal adrenal tissues. Interestingly, among these 170 genes, 59 are common to our proteome dataset. As observed at the level of the protein expression changes, the hierarchical clustering of these 59 differentially expressed genes efficiently separated the tumor samples from the normal adrenal tissue (Figure 6A). Moreover, the expression of 53 of these 59 genes (90\%) shows the same variation trend as the protein expression, both in the cytosol and in the membranes (Figures 6B and Supplementary Figure 2). To visualize whether the deregulated proteins identified in this comparison were highly connected to each other, we performed a protein-protein interaction (PPI) network analysis using Cytoscape ((Shannon et al, 2003), Figure 7). Interestingly, one major significant cluster is composed of proteins that are overexpressed both at the protein and at the gene levels (blue squares). The cluster includes proteins involved in the secretory granule composition such as various chromogranins (CHGA, CHGB, SCG2, SCG3, SCG5), in catecholamine synthesis or in hormone processing (DBH, PCSK1, PCSK2, CPE, PAM), in granule docking and fusion such as different SNAREs or SNAREs interacting proteins (SNAP25, STX1A, SYTL4, STXBP1, SYT1) and Rab GTPases (RAB3A, RAB3D, RAB27B). 


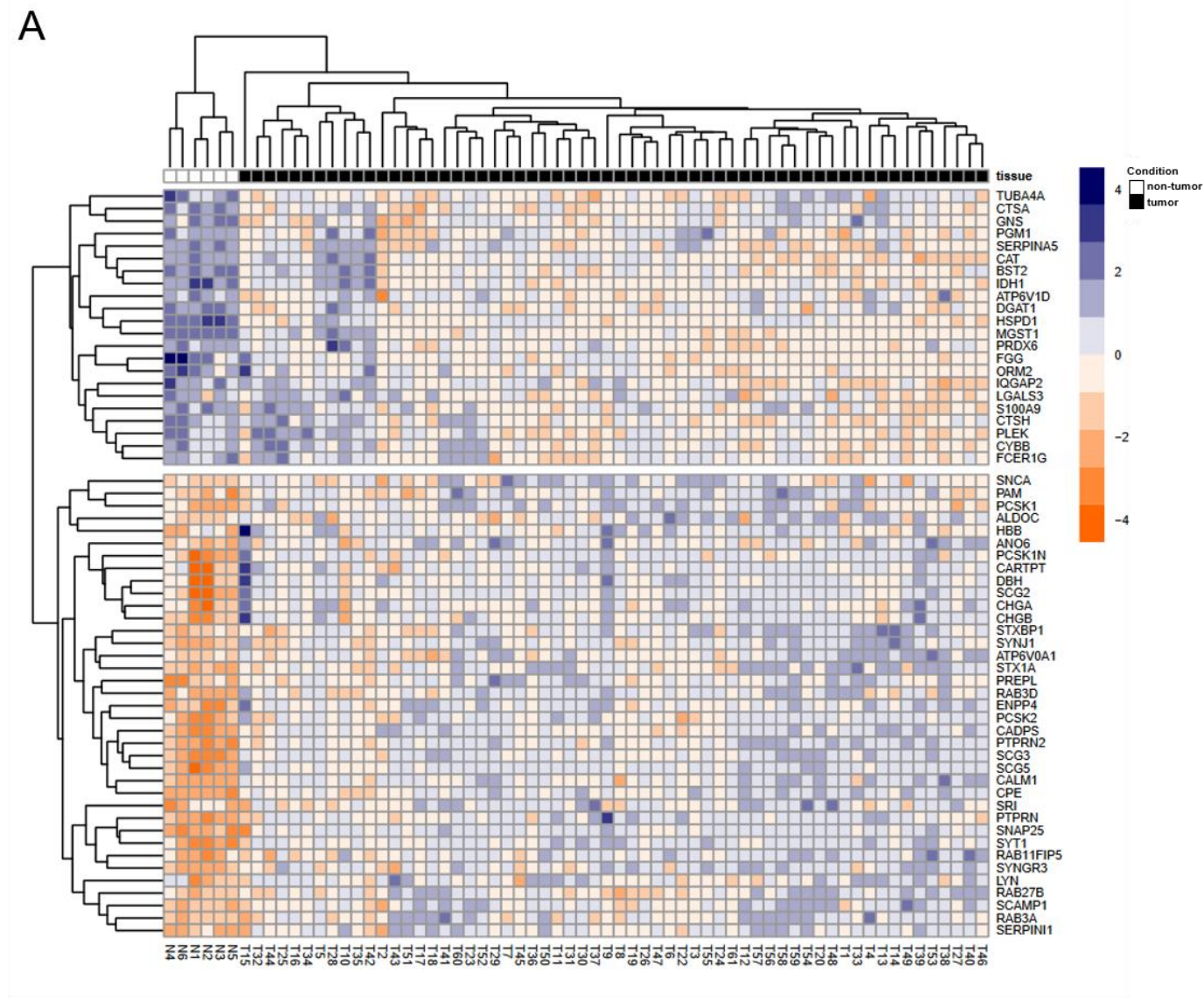

B

Cytosol

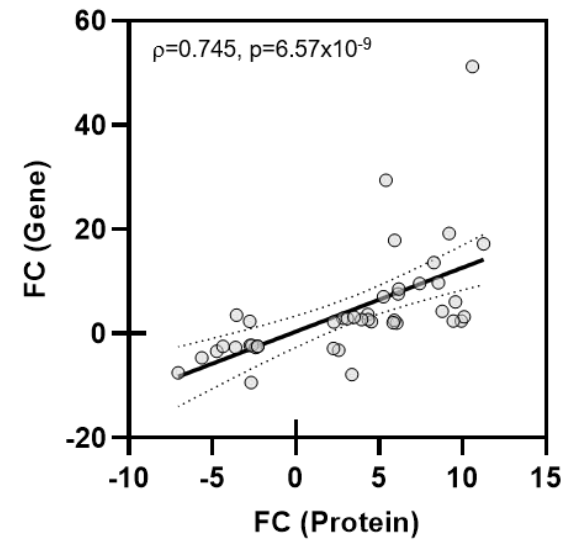

Membrane

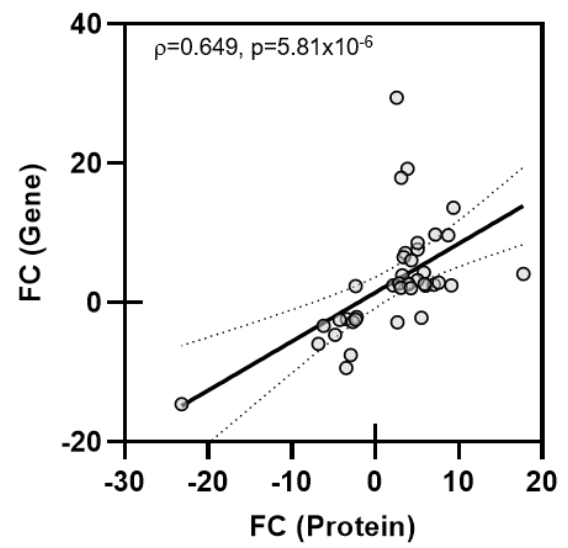

Figure 6: Comparison of the proteome dataset with a published gene expression analysis of 60 Pheo and 6 normal adrenal medulla tissues. (A) Unsupervised hierarchical clustering of selected gene expression profiles $(n=59)$ for 6 non-tumor adrenal medulla (in white) and 60 pheochromocytomas (in black) tissues from Lopez-Jimenez et al. (2010). The color scale illustrates the relative level of gene expression: blue, highly expressed gene; red, low expressed gene. (B) A significant positive correlation was evidenced between the fold changes $(F C)$ in expression of genes and corresponding cytosolic or membrane proteins of the exocytosis pathway. Linear regression (solid line) and $95 \%$ confidence bands (the regions delineated by dotted lines) are shown. 


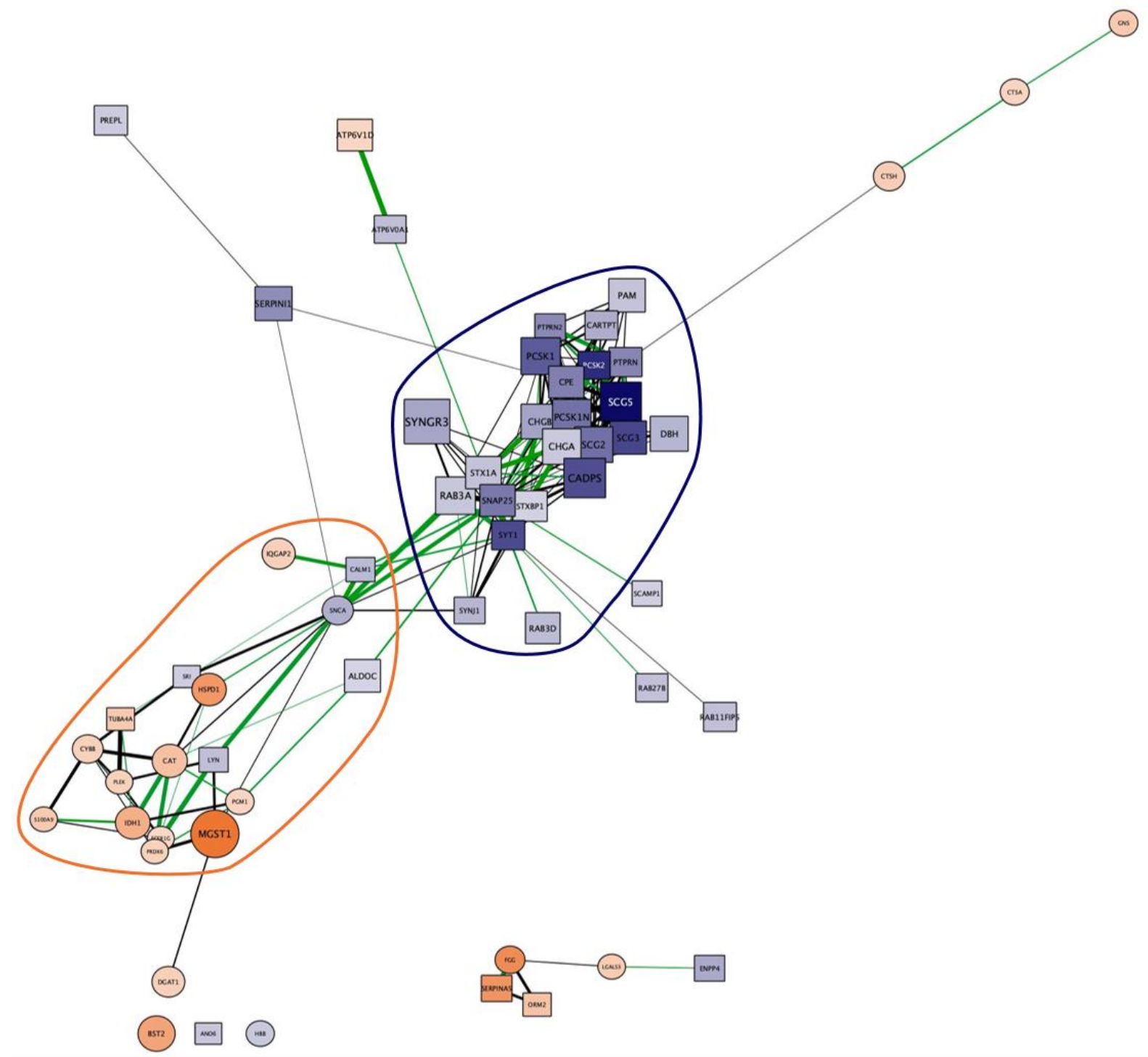

Nodes

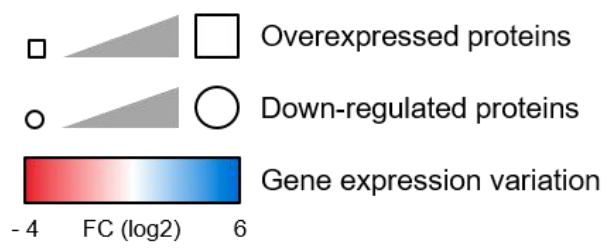

Edges / Protein-protein interaction (PPI)

Experimentaly validated PPI

PPI Score

Figure 7: Protein-protein interaction (PPI) network analysis of the exocytic proteins modulated in Pheo at the transcriptomic and protein level. The PPI network was generated using Cytoscape. Overexpressed and downregulated proteins are represented by square and round nodes, respectively and the level of protein expression is proportional to their size whereas the mRNA expression variation is color coded as indicated. Therefore blue squares and red circles represent candidate for which both protein and $m R N A$ are overexpressed or downregulated, respectively. The 2 first clusters identified by the CytoCluster plugin are outlined in blue $\left(p=2.74 \times 10^{-9}\right)$ and red $\left(p=3.65 \times 10^{-6}\right)$. Note that the variation observed at the protein and mRNA level goes in the same direction for 53 proteins out of $59(90 \%)$. 
Finally, to further validate our dataset, we analyzed the global expression change of some key overexpressed proteins present in the main exocytic cluster identified with Cytoscape. To do so, we performed a multiplexed MRM MS assay in total protein homogenates prepared from another independent cohort of 25 pairs of human Pheo and their matched non-tumor tissue (Croise et al, 2016). As MRM is a targeted MS approach that uses synthetic peptide reference standards, it is used to confirm and quantify the presence of proteins of interest on smaller amounts of sample with high sensitivity, which eliminates the need for fractionation (Keshishian et al, 2007). As observed for the subcellular fractions, using MRM MS we found that the expression of every protein identified in the PPI analysis was also significantly increased in Pheos compared with the matched adjacent non-tumor adrenal tissue (Figure 8).

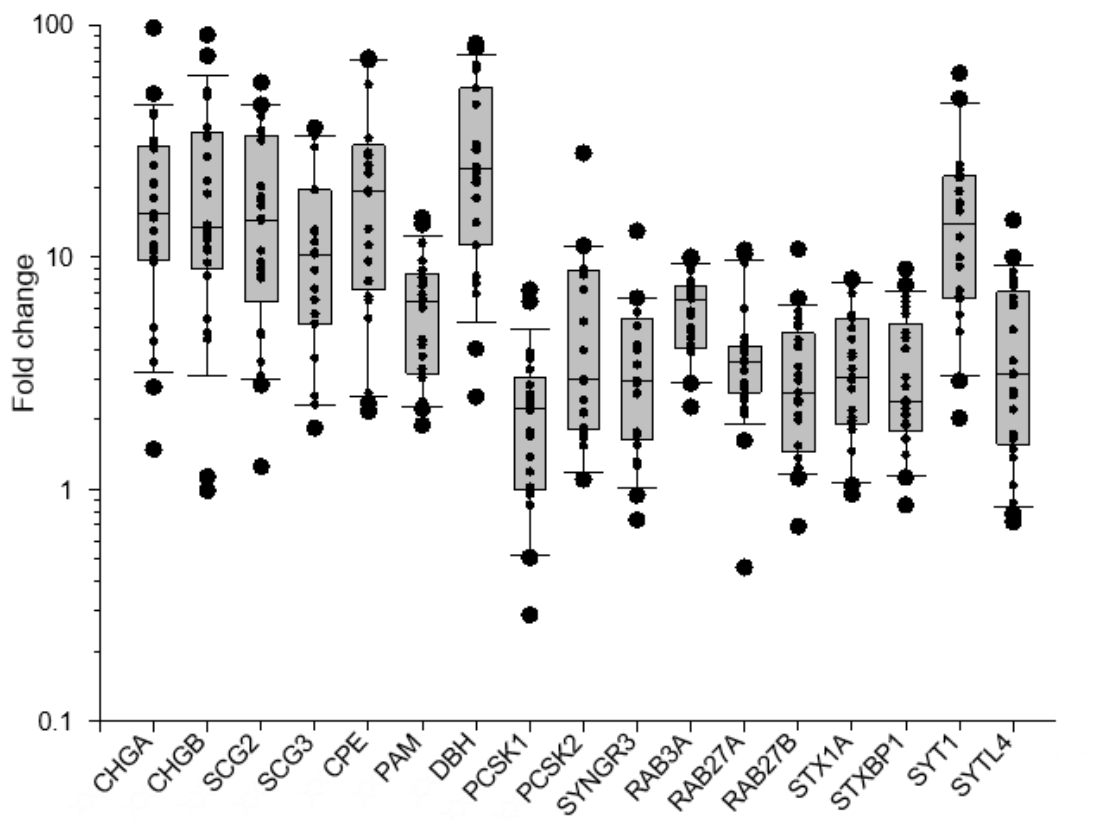

Figure 8: Global variation of key exocytic proteins expression in human Pheo tissue. Expression variation of the indicated proteins was quantified at the protein level by MRM-MS in 25 pairs of human Pheo normalized to their matched adjacent non-tumor tissue. Box-and-whisker diagrams illustrate the distribution of protein expression fold change (FC) for the 25 Pheos. 


\section{Discussion}

Dysfunction of hormones and neuropeptides secretion in NETs is a serious health issue. Patients with midgut primary carcinoids have increased serotonin and metabolite secretion, corresponding to higher metastatic tumor burdens (Onaitis et al, 2000). Hypersecretion of serotonin by carcinoid tumor from the gastro-intestinal tract can trigger carcinoid syndrome, which is associated with severe consequences such as flushing, diarrhea, bronchoconstriction and cardiac valvular disease (Onaitis et al., 2000). Acromegaly often result from excessive secretion of growth hormone by pituitary adenoma (Dineen et al, 2017). Excessive level of circulating catecholamines in patients with Pheo can trigger life-threatening medical problems such as cardiopathy and stroke (Y-Hassan \& Falhammar, 2020; Zhang et al., 2017). Moreover, enhanced secretory activity of NET cells may develop over time with negative impact on prognosis. For example, silent pituitary adenoma can evolve into an active secreting adenoma whereas non-functional pancreatic tumors can become hormonally active, hence turning to a more aggressive tumor phenotype (Brown et al, 2006; Daems et al, 2009; Juhlin et al, 2019). Small cell lung cancer (SCLC) is a high-grade malignant cancer due to the progressive neuroendocrine nature of SCLC cells that secrete a variety of neuropeptides, together with growth factors that all dramatically accelerate the invasive growth by their autocrine action (Cuttitta et al, 1985; Song et al, 2003). Altogether, these few examples taken from a longer list clearly reveals that dysfunction of the secretory pathways in NETs can lead to severe clinical complications and can also impact the tumor development and prognosis. Today, a clear unmet need is to identify the cellular and molecular mechanisms triggering hypersecretory activity in NETs.

The aim of the present study was thus to uncover part of the mechanisms triggering catecholamine hypersecretion in human Pheo cells. To do so, we have used carbon fiber amperometry recordings to analyze catecholamine secretion on individual tumor cells cultured directly from freshly resected human Pheos. In parallel, we have analyzed the expression level of various proteins involved in calcium-regulated exocytosis by differential mass spectrometry methods applied on human Pheo tissues.

At the cellular level, several hypotheses which may not be mutually exclusive could explain the hypersecretory phenotype of Pheo: i) a leakage of catecholamines through the constitutive secretory pathway, ii) a global increase in the quantity of catecholamines in the secretory granules, iii) a simple mass effect, as the number of cells increases within the tumor and iv) a dysfunction of the calcium-regulated secretory pathway. Interestingly, our amperometric analysis has allowed us to identify the later possibility as a likely cause of this phenomenon. First, leakage of catecholamines in resting tumor cells does probably not occur as we never observed any spontaneous amperometric spike in the absence of cell stimulation (data not shown). Second, an increase of catecholamines in the secretory granules is rather unlikely since in most cases, quantal size of individual secretory events was not increased. Third, we showed that the number of exocytic events is significantly increased in single tumor 
chromaffin cells compared to non-tumor cells indicating that the cell proliferation within the tumor cannot be responsible alone for the hypersecretion phenotype. Moreover, by analyzing the spike kinetics, we have also observed that, for many patients, exocytic events tend to be faster. Altogether, our data clearly demonstrated that the regulation of calcium-regulated exocytosis is highly perturbed in tumor cells. To our knowledge, this is the first report analysing the catecholamine secretion using carbon fiber amperometry recording directly performed on human tumor cells from freshly resected pheochromocytomas.

The specific step of the exocytic pathway and which proteins might be involved in this amplified secretory activity remain to be explored in details. However, a significant increase in spike frequency can be consistent with an increase in efficiency of the different steps upstream of the fusion process including recruitment, docking and priming or with a greater calcium sensitivity of the exocytosis machinery. Faster kinetics of the exocytotic events might also reflect a direct effect on the fusion process. Through the differential mass spectrometry analysis, we have identified several proteins involved in the regulation of these various step of exocytosis, that are significantly over-expressed in the tumor tissue compared to the nontumor tissue. Among them, some are known to affect the amperometric spike frequency and/or the kinetics of the spikes when their expression changes in chromaffin cells. This is the case for example of SNARE proteins (SNAP25, Syntaxin1), as well as for proteins regulating the SNARE complex (Synaptotagmin-1 and -7) or for the actin cytoskeleton organization (Rab27A or Annexin-A2) (Desnos et al, 2003; Fang et al, 2008; Gabel et al, 2015; Tawfik et al, 2021). Of note, among the core exocytotic machinery the calcium sensor synaptotagmin-1 was found to be among the most overexpressed in tumor cells (Figure 8), which could lead to an increase in calcium sensitivity and probability of release. Finally, it must be mentioned that at this stage, we cannot rule out an increase of the number of secretory granules in tumor cells as various specific soluble cargos of secretory granules, like different chromogranins or enzymes involved in hormone processing, were also found to be overexpressed. These observations are in line with previous reports indicating that chromogranins or chromogranin-derived peptides are highly expressed in Pheo (Guerin et al, 2010), and often found at higher levels in human fluids, which makes some of the proteins identified in our screen biomarker candidates.

To conclude, we have reported here that calcium-regulated exocytosis is deregulated in human Pheo cells and we have described tumor-associated expression changes of various key players of the exocytic pathway. The next challenge will be to understand how exactly these changes lead to the hypersecretion of catecholamines by the tumor. Moreover, a key unmet need is to find molecules able to prevent the catecholamine hypersecretion directly from the tumor cells. Of note, we have recently identified the somatostatin analog pasireotide (SOM230) as a bona fide inhibitor of Pheo hypersecretion (Streit et al, 2021), but the probable mechanism of action of this drug involves an inhibition of the cholinergic stimulation, which may prove to affect the activity of a large variety of secretory cells possessing nicotinic receptors. There is therefore a need to correct hypersecretion by identifying specific alterations in the secretory machinery whose potential candidates are identified in this study. 


\section{Material and methods}

\section{Subjects and samples}

The medical files of patients with Pheo in 2 French centers (CHRU, Nancy and NHC, Strasbourg) between 2013 and 2020 were retrospectively reviewed. We collected initial diagnosis, including a clinical examination looking for hormonal-related symptoms and biological analysis. As recommended by the Endocrine Society clinical practice guideline published in 2014 (Lenders et al, 2014), Pheo genetic testing was proposed to identify germline mutations in the major susceptibility genes (SDHB, SDHC, SDHD, VHL, NF1, RET, TMEM127, MAX) using Sanger sequencing and multiplex ligation-dependent probe amplification (MLPA). Then, as recommended in the consensus statement published in 2017 (Group et al, 2017), next-generation-sequencing (NGS)-based diagnostic was carried out for more recent patients. Biological analysis comprised the measurement of metanephrine (MN) and normetanephrine (NMN) levels (in urine and/or plasma). When available, chromogranin A (CGA) measurements were also registered. Levels of free MN, NMN and CGA in plasma, as well as urinary levels of MN and NMN are presented as ratios normalized by the upper limits of normal (ULN). Plasma and urinary MN or NMN levels reaching two-fold the upper limit of the normal range and/or CGA exceeding the upper limit of the normal range was defined as the threshold of abnormal hormonal secretion (Lenders et al., 2020). The ULN of free MN and NM were 4.05 and $9.8 \mathrm{nmol} / \mathrm{L}$ in plasma and 1625 and $2620 \mathrm{nmol} / 24 \mathrm{~h}$ in urine, respectively. The upper reference limit for CGA was $100 \mathrm{mg} / \mathrm{L}$. Catecholamine-producing phenotype of Pheo were categorized as previously described (Eisenhofer et al, 2005): adrenergic (AD) phenotype, when MN content exceeded $10 \%$ of the combined MN and NMN contents, or noradrenergic (NAD) phenotype when MN content remained below $10 \%$ of the combined MN and NMN contents. Pathological evaluation was reviewed, including tumor size, Ki-67 result and the PASS (Pheochromocytoma of the Adrenal Gland Scaled Score) as previously described (Thompson, 2002). Biological and clinical characteristics are summarized in Tables 1 and 2 whereas details per patient are described in Supplementary Table 1.

\section{Primary culture of human pheochromocytoma cells}

Human tumor cells were cultured from freshly resected Pheo following surgery (Moog et al, 2018). In the operating room and immediately after the resection, the adrenal gland was cut longitudinally in two parts. Roughly a $1 \mathrm{~cm}^{3}$ piece of tumor tissue was dissected and immediately plunged into ice cold transport medium $\left(\mathrm{Ca}^{2+}\right.$ - and $\mathrm{Mg}^{2+}$-free Hank's Balanced Salt Solution (CMF HBSS, Sigma) supplemented with 0.2\% Fetal Bovine Serum (FBS, Gibco) and $1 \%$ penicillin/streptomycin (Sigma) or MACS Medium Tissue Storage solution (Miltenyi Biotec). Up to 3 hours after resection, the tumor sample was minced into $1 \mathrm{~mm}^{3}$ pieces in a dish containing CMF HBSS. Chunks were collected, centrifuged at $250 \mathrm{~g}$ for $5 \mathrm{~min}$ at room temperature and the pellet resuspended in $15 \mathrm{~mL}$ of complete medium (RPMI 1640 GlutaMAX $^{\mathrm{TM}}$ (Gibco), 15\% FBS, 1\% penicillin/streptomycin). Red blood cells, debris and fat were separated from minced tissue by sedimentation for $15 \mathrm{~min}$ at room temperature. The supernatant was removed and $15 \mathrm{~mL}$ of complete medium were added to the pellet before centrifugation at $250 \mathrm{~g}$ for $5 \mathrm{~min}$. Tumor pieces were resuspended in HBSS (in 10 times the tissue volume), containing $1.5 \mathrm{mg} / \mathrm{mL}$ of collagenase B (Roche) and $1 \mathrm{mg} / \mathrm{mL}$ of the protease 
dispase II (Gibco) and gently rocked for $45 \mathrm{~min}$ at $37^{\circ} \mathrm{C} .5 \mathrm{~min}$ before the end of protease digestion, $0.1 \mathrm{mg} / \mathrm{mL}$ DNase I (Roche) was added to remove potential DNA clumps. Samples were left for a few minutes to sediment at room temperature and supernatant recovered (fraction 1). The pellet was resuspended in $5 \mathrm{~mL}$ of CMF HBSS and triturated for a couple of minutes to dislodge tumor cells from chunks. The remaining pieces were left few minutes to sediment and the supernatant recovered (fraction 2). Both fractions were centrifuged at $800 \mathrm{~g}$ for $5 \mathrm{~min}$ at room temperature. Cell pellets were resuspended in $2 \mathrm{~mL}$ of CMF HBSS. $4 \mathrm{~mL}$ of Red Blood Cell Lysis Buffer (Roche) were added before being gently rocked for $10 \mathrm{~min}$ at room temperature. The fractions were centrifuged at $500 \mathrm{~g}$ for $5 \mathrm{~min}$ and resuspended into complete medium. Cell viability and density were estimated under a microscope and $300 \mu \mathrm{L}$ of cell suspension were seeded into type I collagen (Corning)-coated $35 \mathrm{~mm}$ dishes (MatTek). Cells were left to adhere overnight at $37^{\circ} \mathrm{C}$ in an incubator with water-saturated and $5 \% \mathrm{CO}_{2}$ atmosphere. $2 \mathrm{~mL}$ of complete RPMI were added the following day and cells were used within two days.

\section{Carbon fiber amperometry}

Human tumor cells from freshly resected pheochromocytoma were washed with Locke's solution $\left(140 \mathrm{mM} \mathrm{NaCl}, 4.7 \mathrm{mM} \mathrm{KCl}, 2.5 \mathrm{mM} \mathrm{CaCl}_{2}, 1.2 \mathrm{mM} \mathrm{KH}_{2} \mathrm{PO}_{4}, 1.2 \mathrm{mM} \mathrm{MgSO}_{4}, 11\right.$ $\mathrm{mM}$ glucose, $0.01 \mathrm{mM}$ EDTA and $15 \mathrm{mM}$ HEPES, $\mathrm{pH}$ 7.5) and processed for catecholamine release measurements by amperometry as previously described (Houy et al, 2015; Tanguy et $a l, 2020)$. A carbon fiber electrode of $5 \mu \mathrm{m}$ diameter (ALA Scientific Instruments) was held at a potential of $+650 \mathrm{mV}$ compared with the reference electrode $(\mathrm{Ag} / \mathrm{AgCl})$ and approached close to one cell. Secretion of catecholamines was induced by a $10 \mathrm{~s}$ pressure ejection of a $100 \mu \mathrm{M}$ nicotine (Sigma) solution from a micropipette (Femtotips ${ }^{\circledR}$, Eppendorf) positioned $10 \mu \mathrm{m}$ from the cell and recorded over $60 \mathrm{~s}$. The amperometric recordings were performed with an AMU130 amplifier (Radiometer Analytical), calibrated at $5 \mathrm{kHz}$, and digitally low-pass filtered at $1 \mathrm{kHz}$. Analysis of the amperometric recordings was performed as previously described with a macro (laboratory of Dr. R. Borges; http://webpages.ull.es/users/rborges/ ) written for Igor software (WaveMetrics), allowing automatic spike detection and extraction of spike parameters (Segura et al, 2000). The spike parameters analysis was restricted to spikes with amplitudes higher than $5 \mathrm{pA}$, which were considered as exocytic events. All spikes identified by the program were visually inspected. Overlapping spikes and spikes with aberrant shapes were discarded for parameters analysis. Quantal size (spike charge, Q) of each individual spike was measured by calculating the spike area above the baseline. Spike area is defined as the time integral of each transient current, Imax as the height of each spike, half-width as the width of each spike at half its height $\left(T_{1 / 2}\right)$ and $T_{\text {peak }}$ as the spike rise time (Figure 1A).

\section{Tissue fractionation}

Frozen tumor and matched non-tumor adjacent tissues were cut into small pieces $\left(\sim 10 \mathrm{~mm}^{3}\right)$, and $3 \mathrm{~mL}$ of homogenization buffer $(0.25 \mathrm{M}$ sucrose, $10 \mathrm{mM}$ Tris $\mathrm{pH} 7.4,100$ units $/ \mathrm{mL}$ of DNase I, $5 \mathrm{mM} \mathrm{MgCl} 2$, Complete protease inhibitor EDTA-free cocktail) was added per tissue sample, homogenized twice for $10 \mathrm{~s}$ and one time for $20 \mathrm{~s}$ using a polytron set at speed 4.0. Homogenates were filtered through a $180 \mu \mathrm{m}$ nylon and brought to $3 \mathrm{~mL}$ with the homogenization buffer, if necessary. Light membranes were obtained by isopycnic 
centrifugation using discontinuous sucrose gradients in which samples brought to $1.4 \mathrm{M}$ sucrose were layered by $1.2 \mathrm{M}$ and $0.8 \mathrm{M}$ sucrose. After centrifugation at $155,000 \mathrm{~g}$ for 2 hours at $4^{\circ} \mathrm{C}$, the light membrane fraction located at the $0.8 \mathrm{M}$ to $1.2 \mathrm{M}$ sucrose interface was collected, snapfrozen in liquid nitrogen and stored at $-80^{\circ} \mathrm{C}$. The light membrane fraction is enriched with plasma membrane, Golgi, endosomes and secretory pathway associated membranes. The cytosol fractions were obtained by centrifuging $200 \mu \mathrm{L}$ of crude homogenates at 150,000 $\mathrm{g}$ for 1 hour at $4{ }^{\circ} \mathrm{C}$. The supernatant was collected, snap-frozen and stored at $-80^{\circ} \mathrm{C}$.

The amounts of protein were determined using the bicinchoninic acid (BCA) assay according to the manufacturer's instructions (Pierce).

\section{Mass spectrometry analysis}

$30 \mu \mathrm{g}$ of samples (homogenates, cytosol or light membranes) was incubated in a denaturing buffer at final concentration of $7 \mathrm{M}$ urea, $175 \mathrm{mM} \mathrm{NH}_{4} \mathrm{HCO}_{3}, 8.75 \% \mathrm{v} / \mathrm{v}$ acetonitrile and incubated for $30 \mathrm{~min}$ at room temperature. Samples were then diluted to $1 \mathrm{M}$ urea with water and digested with trypsin (Promega) overnight at $37^{\circ} \mathrm{C}$ at a ratio of $1 \mu \mathrm{g}$ of trypsin per $10 \mu \mathrm{g}$ of protein for homogenate and cytosol samples while for light membranes, the ratio was set at $1 \mu \mathrm{g}$ of trypsin per $25 \mu \mathrm{g}$ of proteins. Samples were reduced with $10 \mathrm{mM}$ tris(2carboxyethyl)phosphine (final concentration), incubated for $30 \mathrm{~min}$ at room temperature and then acidified to $0.5 \mathrm{M} \mathrm{HCl}$. The samples were desalted using $\mathrm{C} 18$ 96-well plates (3M Empore). The $\mathrm{C} 18$ eluates from homogenate samples were evaporated and stored at $4{ }^{\circ} \mathrm{C}$ prior to $\mathrm{MS}$ analysis. The $\mathrm{C} 18$ eluates from light membrane and cytosol samples were collected in injection plates for strong cation exchange (SCX), dried by vacuum evaporation and stored at $-20^{\circ} \mathrm{C}$.

To fractionate peptides by SCX chromatography, samples were solubilized with reconstitution buffer $(0.2 \% \mathrm{v} / \mathrm{v}$ formic acid, $10 \% \mathrm{v} / \mathrm{v}$ acetonitrile for light membrane samples; $20 \mathrm{mM}$ $\mathrm{K}_{2} \mathrm{HPO}_{4}, 25 \% \mathrm{v} / \mathrm{v}$ acetonitrile for cytosol samples) and loaded on an SCX column. Three fractions were collected following elution using a salt gradient. At the end of each SCX fractionation batch, the collected fractions were stored at $-80^{\circ} \mathrm{C}$. Once the SCX fractionation was completed, the fractions were freeze-dried and then desalted. The eluates were divided equally into two 96-well plates; one plate for LC-MS/MS analysis and the other plate as a backup. All plates were vacuum evaporated and stored at $-20^{\circ} \mathrm{C}$ until analysis by LC-MS/MS. Samples were resuspended in 92.5/7.5 water/ACN+0.2\% formic acid and analyzed by LCMS/MS on a nanoAcquity UPLC (Waters) coupled to a Q-Exactive mass spectrometer (Thermo). Survey (LC-MS) and tandem mass spectrometry scans (MS/MS) were acquired in the same run. The resolution for the MS and MS/MS scans were 70,000 and 17,500, respectively. Peptide separation was achieved using a Waters nanoAcquity Symmetry UPLC Trap column ( $180 \mu \mathrm{m}$ x $20 \mathrm{~mm}, 5 \mu \mathrm{m}$ particle size $)$ and a Waters nanoAcquity UPLC BEH300 analytical column $(150 \mu \mathrm{m} \times 100 \mathrm{~mm}, 1.7 \mu \mathrm{m}$ particle size). The mobile phases were (A) $0.2 \%$ formic acid in water and (B) $0.2 \%$ formic acid in acetonitrile. For each sample approximately $3.6 \mu \mathrm{g}$ was loaded onto the trap column for $3 \mathrm{~min}$ at a flow rate of $10 \mu \mathrm{L} / \mathrm{min}$. Peptides were separated using a linear gradient $(92.5 \%$ A to $84 \%$ A) for $26 \mathrm{~min}$, followed by (84\% A to $75 \%$ A) for $14 \mathrm{~min}$ and a wash at $60 \% \mathrm{~B}$ for $2 \mathrm{~min}$. The flow rate was $1.8 \mu \mathrm{L} / \mathrm{min}$. Protein identification was accomplished using data acquired by LC-MS/MS. The MS/MS spectra were matched to the corresponding peptide sequences found in the UniProt human protein database using Mascot (Matrix Science, version 2.2.06.) software. 


\section{Multiplexed multiple reaction monitoring (MRM) assay}

For each of the selected proteins, five MRM-suitable peptides were selected by CellCarta's inhouse MRM Peptide Selection software. If possible, peptides that were detected by mass spectrometry were prioritized. The selected peptides were synthesized by JPT Peptide Technologies (Germany). Synthesized peptides were resolubilized in 25\%/75\% water/DMSO $(\mathrm{v} / \mathrm{v})$, pooled and diluted with $0.2 \%$ formic acid in water to a concentration of $200 \mathrm{pmol} / \mathrm{mL}$. This peptide mix was used to develop the MRM assay. The optimal 2 transitions (combination of peptide precursor and fragment ion mass-to-charge ratio that are monitored by the mass spectrometer) per peptide were determined using selected reaction monitoring (SRM)-triggered MS/MS on a QTRAP 5500 instrument (AB Sciex) coupled to a nanoAcquity UPLC (Waters). An SRM transition was predicted for each peptide. The detection of this transition triggered the acquisition of a full MS/MS spectrum of the target peptide. The two most intense fragment ions (b or y fragment ions only) in the MS/MS spectrum for each acquired peptide were recorded by in-house developed software. The mass spectrometer collision energy (CE) was optimized for each transition with 5 different $\mathrm{CE}$ values automatically generated by in-house developed software. A solution containing all synthesized peptides at a concentration of $200 \mathrm{pmoL} / \mathrm{mL}$ was analyzed with the created MRM method. The two best peptides per proteins were selected to be monitored by the MRM assay.

The processed samples were resolubilized with $11 \mu \mathrm{L}$ of a reconstitution solution containing 5 internal standard (IS) peptides each at $100 \mathrm{ng} / \mathrm{mL}$. Eight (8) $\mu \mathrm{L}$ of material $(\sim 10 \mu \mathrm{g})$ was analyzed by LC/MRM-MS. Peptide separation was achieved using a BioBasic C18 column (Thermo) $(320 \mu \mathrm{m}$ x $150 \mathrm{~mm}, 5 \mu \mathrm{m}$ particle size). The mobile phases were (A) $0.2 \%$ formic acid in water and (B) $0.2 \%$ formic acid in acetonitrile. Peptides were separated using a linear gradient $(92.5 \%$ A to $60 \% \mathrm{~A})$ for $21 \mathrm{~min}$, followed by a wash at $60 \% \mathrm{~B}$ for $2 \mathrm{~min}$. The flow rate was $10 \mu \mathrm{L} / \mathrm{min}$. The transition peak areas were integrated using Elucidator software (Rosetta Biosciences) in combination with software developed at CellCarta for automated MRM peak integration.

\section{Data processing and statistical analysis}

For the analysis of the carbon fiber amperometry, the data was first standardized (mean=0 and variance $=1$ ). Data then was normalized by quantile method using preprocessCore $\mathrm{R}$ package. PCA analysis was performed using FactoMineR and factoextra R packages. Spearman's rank order correlation was performed using cor function from stats $\mathrm{R}$ package and plotted using corrplot and ggplot2 R packages. For comparison between paired Tumor ( T) and Non-Tumor (NT) patients, paired Wilcoxon test was performed. For comparison between Tumor (T) patients, non-paired Wilcoxon test was performed.

For the differential expression analysis by mass spectrometry, the intensity values for all detected components were $\log$ (base e) transformed with values < 0 replaced by 0 . Intensity data was normalized to account for small differences in protein concentration between samples. A subset of the samples was used to create a reference sample against which all samples were then normalized. The normalization factors were chosen so that the median of log ratios 
between each sample and the reference sample over all the peptides was adjusted to zero. Intensities below Limit of Detection (LOD=100000) after normalization, were then linearly mapped to the range of (LOD/2, LOD) to avoid spurious large fold changes. Intensities above LOD were not changed. A two-way ANOVA model was used for the peptide level analysis and is defined as follows: $\mathrm{I}_{\mathrm{ijk}}=\mathrm{M}+\mathrm{C}_{\mathrm{i}}+\mathrm{S}_{\mathrm{j}}+\varepsilon_{\mathrm{ijk}}$ where $\mathrm{I}$ is the peptide intensity, $\mathrm{M}$ is the overall average intensity, $\mathrm{C}$ the 'clinical group' factor (matched non tumor and tumor), $\mathrm{S}$ the 'patient' factor that takes into consideration the 'pairing' nature of the data, and $\varepsilon$ random error. FDR (False Discovery Rate) and q-value were calculated, based on the p-values obtained from the ANOVA model, using the Storey Tibshirani method to make multiple testing adjustments. Tukey's HSD (Honestly Significant Difference) method is used to perform post hoc contrast among different groups.

One protein may have several identified and quantified peptides. The following ANOVA model, which is an extension of the two-way ANOVA used above in the peptide level analysis, takes this into consideration by introducing a 'peptide factor' in the model: $\mathrm{I}_{\mathrm{ijkl}}=\mathrm{M}+\mathrm{C}_{\mathrm{i}}+\mathrm{S}_{\mathrm{j}}+\mathrm{P}_{\mathrm{k}}+\varepsilon_{\mathrm{ijkl}}$ where $\mathrm{I}$ is the protein intensity, $\mathrm{M}$ an overall constant, $\mathrm{C}$ the 'clinical group', $\mathrm{S}$ the 'patient' factor, and $\mathrm{P}$ the peptide factor. The number of the levels for $\mathrm{P}$ is proteindependent, equal to the number of identified and quantified peptides for the protein.

For Multiple reaction monitoring (MRM) analysis, differential intensity (DI) ratios were calculated in pair wise comparisons for each transition as the median of the ratio of the normalized intensities of each group. Paired Student's t-test was applied for the expression analysis. Protein-level statistics were also computed by linearly combining the transitions of a given protein into a single variable and then applying a t-test.

All differential expression analysis and data visualization were done using R. PCA analysis was done using prcomp function from stats $\mathrm{R}$ package and plotted using ggplot $2 \mathrm{R}$ package. Volcano plot was performed using EnhancedVolcano function from R package.

\section{Transcriptomic analyses}

Gene expression data were retrieved from the GSE19422 dataset (https://www.ncbi.nlm.nih.gov/geo/query/acc.cgi?acc=GSE19422) (Lopez-Jimenez et al., 2010) which includes 6 normal adrenal medulla and 61 Pheos. Consistently with the proteomic analysis, the 23 paraganglioma samples were not considered. The GSM483021 Pheo sample was excluded from our analysis because its transcriptomic profile, as revealed by clustering and UMAP analyses (data not shown), is similar to that of normal samples suggesting that it is misidentified. The expression level of each gene was calculated as the geometric mean of the significantly differentially expressed probes identified with the GEO2R web tool using a Benjamin-Hochberg FDR correction (q-values < 0.05). Genes of the regulated exocytosis (\#BPGO:0045055) and secretory granule (\#CCGO:0030141) GO terms were then selected for further analysis. Unsupervised hierarchical clustering was performed with Bioconductor (v.3.13) and R software (v.4.1.0) using Pearson correlation as distance calculation and complete linkage. The Fold change (FC) for each gene was calculated from the median expression values for the normal and Pheo groups and only those with a FC greater than or equal to 2 were retained for further analysis. 
The correlation between the expression level of common genes and proteins was evaluated in both cytosolic and membrane fractions using Spearman correlation (GraphPad Prism v.8.1). In order to highlight functional clusters, an integrative analysis was conducted with Cytoscape software (v.3.8.2, (Shannon et al., 2003)) using expression data and protein interaction data retrieved from STRING-DB (v.11.5, https://string-db.org/, (Szklarczyk et al, 2021)). An edgeweighted force directed layout has been applied to the interaction network. Gene/protein clusters were identified using the CytoCluster plugin for Cytoscape using the default settings except for minimum size: 6, minimum density: 0.25, Edge weights: Feature Distance, Node penalty:3. 
bioRxiv preprint doi: https://doi.org/10.1101/2021.11.02 466874 this version posted November 5,2021 . The copyright holder for this preprint (which was not certified by peer review) is the author/funder, who has granted bioRxiv a license to display the preprint in perpetuity. It is made available under aCC-BY-NC-ND 4.0 International license.

\section{Ethics approval and consent to participate}

The present study used the data and the human biological material of the biological collection "Approche moléculaire des tumeurs corticosurrénaliennes" which was agreed by the "Comité de Protection des Personnes Est III" ethical advisory committee, and was conducted according to currently accepted ethical guidelines, including informed written consent approval signed by all patients prior to inclusion.

\section{Funding and acknowledgements}

This work was financially supported by ITMO Cancer AVIESAN (Alliance Nationale pour les Sciences de la Vie et de la Santé, National Alliance for Life Sciences \& Health) within the framework of the Cancer Plan to SG and LB (Single Cell $2018 \mathrm{~N}^{\circ}$ 19CS004-00); by the University of Strasbourg Institute for Advanced Study (USIAS) for a Fellowship, within the French national programme "Investment for the future" (IdEx-Unistra) to SG; by the Conseil Régional de Normandie to $\mathrm{CD}$; by grants from the Agence Nationale pour la Recherche ("SecretoNET", No ANR-16-CE17-0022-01) and from the Ligue contre le Cancer to SG (CCIR Grand-Est) and to CD (Comité Normand); by a fellowship from la Fondation pour la Recherche Médicale (FRM; FDM201806005916) to SM. INSERM is providing salary to SG and NV.

\section{Conflict of interest}

The authors declare that there is no conflict of interest that could be perceived as prejudicing the impartiality of the research reported. 
bioRxiv preprint doi: https://doi.org/10.1101/2021.11.02.466874; this version posted November 5,2021 . The copyright holder for this preprint (which was not certified by peer review) is the author/funder, who has granted bioRxiv a license to display the preprint in perpetuity. It is made available under aCC-BY-NC-ND 4.0 International license.

\section{References}

Anantharam A, Kreutzberger AJB (2019) Unraveling the mechanisms of calcium-dependent secretion. J Gen Physiol 151: 417-434

Bader MF, Holz RW, Kumakura K, Vitale N (2002) Exocytosis: the chromaffin cell as a model system. Ann N Y Acad Sci 971: 178-183

Brown RL, Muzzafar T, Wollman R, Weiss RE (2006) A pituitary carcinoma secreting TSH and prolactin: a non-secreting adenoma gone awry. Eur J Endocrinol 154: 639-643

Burgoyne RD, Morgan A (2003) Secretory granule exocytosis. Physiol Rev 83: 581-632

Croise P, Houy S, Gand M, Lanoix J, Calco V, Toth P, Brunaud L, Lomazzi S, Paramithiotis E, Chelsky D et al (2016) Cdc42 and Rac1 activity is reduced in human pheochromocytoma and correlates with FARP1 and ARHGEF1 expression. Endocr Relat Cancer 23: 281-293

Cuttitta F, Carney DN, Mulshine J, Moody TW, Fedorko J, Fischler A, Minna JD (1985) Autocrine growth factors in human small cell lung cancer. Cancer Surv 4: 707-727

Daems T, Verhelst J, Michotte A, Abrams P, De Ridder D, Abs R (2009) Modification of hormonal secretion in clinically silent pituitary adenomas. Pituitary 12: 80-86

Desnos C, Schonn JS, Huet S, Tran VS, El-Amraoui A, Raposo G, Fanget I, Chapuis C, Menasche G, de Saint Basile G et al (2003) Rab27A and its effector MyRIP link secretory granules to F-actin and control their motion towards release sites. J Cell Biol 163: 559-570

Dineen R, Stewart PM, Sherlock M (2017) Acromegaly. QJM 110: 411-420

Eisenhofer G, Lenders JW, Goldstein DS, Mannelli M, Csako G, Walther MM, Brouwers FM, Pacak K (2005) Pheochromocytoma catecholamine phenotypes and prediction of tumor size and location by use of plasma free metanephrines. Clin Chem 51: 735-744

Fang Q, Berberian K, Gong LW, Hafez I, Sorensen JB, Lindau M (2008) The role of the C terminus of the SNARE protein SNAP-25 in fusion pore opening and a model for fusion pore mechanics. Proc Natl Acad Sci U S A 105: 15388-15392

Fathali H, Cans AS (2018) Amperometry methods for monitoring vesicular quantal size and regulation of exocytosis release. Pflugers Arch 470: 125-134

Gabel M, Delavoie F, Demais V, Royer C, Bailly Y, Vitale N, Bader MF, Chasserot-Golaz S (2015) Annexin A2-dependent actin bundling promotes secretory granule docking to the plasma membrane and exocytosis. J Cell Biol 210: 785-800

Gasman S, Vitale N (2017) Lipid remodelling in neuroendocrine secretion. Biol Cell 109: 381390

Group NGSiPS, Toledo RA, Burnichon N, Cascon A, Benn DE, Bayley JP, Welander J, Tops CM, Firth H, Dwight T et al (2017) Consensus Statement on next-generation-sequencingbased diagnostic testing of hereditary phaeochromocytomas and paragangliomas. Nat Rev Endocrinol 13: 233-247

Guerin M, Guillemot J, Thouennon E, Pierre A, El-Yamani FZ, Montero-Hadjadje M, Dubessy C, Magoul R, Lihrmann I, Anouar Y et al (2010) Granins and their derived peptides in normal and tumoral chromaffin tissue: Implications for the diagnosis and prognosis of pheochromocytoma. Regul Pept 165: 21-29

Houy S, Estay-Ahumada C, Croise P, Calco V, Haeberle AM, Bailly Y, Billuart P, Vitale N, Bader MF, Ory S et al (2015) Oligophrenin-1 Connects Exocytotic Fusion to Compensatory Endocytosis in Neuroendocrine Cells. J Neurosci 35: 11045-11055

Juhlin CC, Skoglund S, Juntti-Berggren L, Karlberg M, Calissendorff J (2019) Non-functioning neuroendocrine pancreatic tumors transforming to malignant insulinomas - four cases and review of the literature. Neuro Endocrinol Lett 40: 175-183

Keshishian H, Addona T, Burgess M, Kuhn E, Carr SA (2007) Quantitative, multiplexed assays for low abundance proteins in plasma by targeted mass spectrometry and stable isotope dilution. Mol Cell Proteomics 6: 2212-2229 
bioRxiv preprint doi: https://doi.org/10.1101/2021.11.02.466874; this version posted November 5,2021 . The copyright holder for this preprint (which was not certified by peer review) is the author/funder, who has granted bioRxiv a license to display the preprint in perpetuity. It is made available under aCC-BY-NC-ND 4.0 International license.

Lang T, Jahn R (2008) Core proteins of the secretory machinery. Handb Exp Pharmacol: 107127

Lenders JW, Duh QY, Eisenhofer G, Gimenez-Roqueplo AP, Grebe SK, Murad MH, Naruse M, Pacak K, Young WF, Jr., Endocrine S (2014) Pheochromocytoma and paraganglioma: an endocrine society clinical practice guideline. J Clin Endocrinol Metab 99: 1915-1942

Lenders JWM, Kerstens MN, Amar L, Prejbisz A, Robledo M, Taieb D, Pacak K, Crona J, Zelinka T, Mannelli M et al (2020) Genetics, diagnosis, management and future directions of research of phaeochromocytoma and paraganglioma: a position statement and consensus of the Working Group on Endocrine Hypertension of the European Society of Hypertension. J Hypertens 38: 1443-1456

Lopez-Jimenez E, Gomez-Lopez G, Leandro-Garcia LJ, Munoz I, Schiavi F, Montero-Conde C, de Cubas AA, Ramires R, Landa I, Leskela S et al (2010) Research resource: Transcriptional profiling reveals different pseudohypoxic signatures in SDHB and VHLrelated pheochromocytomas. Mol Endocrinol 24: 2382-2391

Malacombe M, Bader MF, Gasman S (2006) Exocytosis in neuroendocrine cells: new tasks for actin. Biochim Biophys Acta 1763: 1175-1183

Moog S, Houy S, Chevalier E, Ory S, Weryha G, Rame M, Klein M, Brunaud L, Gasman S, Cuny T (2018) 18F-FDOPA PET/CT Uptake Parameters Correlate with Catecholamine Secretion in Human Pheochromocytomas. Neuroendocrinology 107: 228-236

Mosharov EV, Sulzer D (2005) Analysis of exocytotic events recorded by amperometry. Nat Methods 2: 651-658

Onaitis MW, Kirshbom PM, Hayward TZ, Quayle FJ, Feldman JM, Seigler HF, Tyler DS (2000) Gastrointestinal carcinoids: characterization by site of origin and hormone production. Ann Surg 232: 549-556

Pappachan JM, Tun NN, Arunagirinathan G, Sodi R, Hanna FWF (2018) Pheochromocytomas and Hypertension. Curr Hypertens Rep 20: 3

Pourian M, Mostafazadeh DB, Soltani A (2015) Does this patient have pheochromocytoma? A systematic review of clinical signs and symptoms. J Diabetes Metab Disord 15: 11

Segura F, Brioso MA, Gomez JF, Machado JD, Borges R (2000) Automatic analysis for amperometrical recordings of exocytosis. J Neurosci Methods 103: 151-156

Shannon P, Markiel A, Ozier O, Baliga NS, Wang JT, Ramage D, Amin N, Schwikowski B, Ideker T (2003) Cytoscape: a software environment for integrated models of biomolecular interaction networks. Genome Res 13: 2498-2504

Song P, Sekhon HS, Jia Y, Keller JA, Blusztajn JK, Mark GP, Spindel ER (2003) Acetylcholine is synthesized by and acts as an autocrine growth factor for small cell lung carcinoma. Cancer Res 63: 214-221

Streit L, Moog S, Hugel S, Rame M, Tanguy E, Andry V, Schmid HA, Brunaud L, Bihain F, Nomine-Criqui C et al (2021) Somatostatin analogue pasireotide (SOM230) inhibits catecholamine secretion in human pheochromocytoma cells. Cancer Lett

Szklarczyk D, Gable AL, Nastou KC, Lyon D, Kirsch R, Pyysalo S, Doncheva NT, Legeay M, Fang T, Bork P et al (2021) The STRING database in 2021: customizable protein-protein networks, and functional characterization of user-uploaded gene/measurement sets. Nucleic Acids Res 49: D605-D612

Tanguy E, Coste de Bagneaux P, Kassas N, Ammar MR, Wang Q, Haeberle AM, Raherindratsara J, Fouillen L, Renard PY, Montero-Hadjadje M et al (2020) Mono- and Poly-unsaturated Phosphatidic Acid Regulate Distinct Steps of Regulated Exocytosis in Neuroendocrine Cells. Cell Rep 32: 108026

Tawfik B, Martins JS, Houy S, Imig C, Pinheiro PS, Wojcik SM, Brose N, Cooper BH, Sorensen JB (2021) Synaptotagmin-7 places dense-core vesicles at the cell membrane to promote Munc13-2- and $\mathrm{Ca}(2+)$-dependent priming. Elife 10 
Thompson LD (2002) Pheochromocytoma of the Adrenal gland Scaled Score (PASS) to separate benign from malignant neoplasms: a clinicopathologic and immunophenotypic study of 100 cases. Am J Surg Pathol 26: 551-566

Y-Hassan S, Falhammar H (2020) Cardiovascular Manifestations and Complications of Pheochromocytomas and Paragangliomas. J Clin Med 9

Zandee WT, Kamp K, van Adrichem RC, Feelders RA, de Herder WW (2017) Effect of hormone secretory syndromes on neuroendocrine tumor prognosis. Endocr Relat Cancer 24: R261-R274

Zhang R, Gupta D, Albert SG (2017) Pheochromocytoma as a reversible cause of cardiomyopathy: Analysis and review of the literature. Int J Cardiol 249: 319-323 
bioRxiv preprint doi: https://doi.org/10.1101/2021.11.02.466874 this version posted November 5,2021 . The copyright holder for this preprint (which was not certified by peer review) is the author/funder, who has granted bioRxiv a license to display the preprint in perpetuity. It is made available under aCC-BY-NC-ND 4.0 International license.

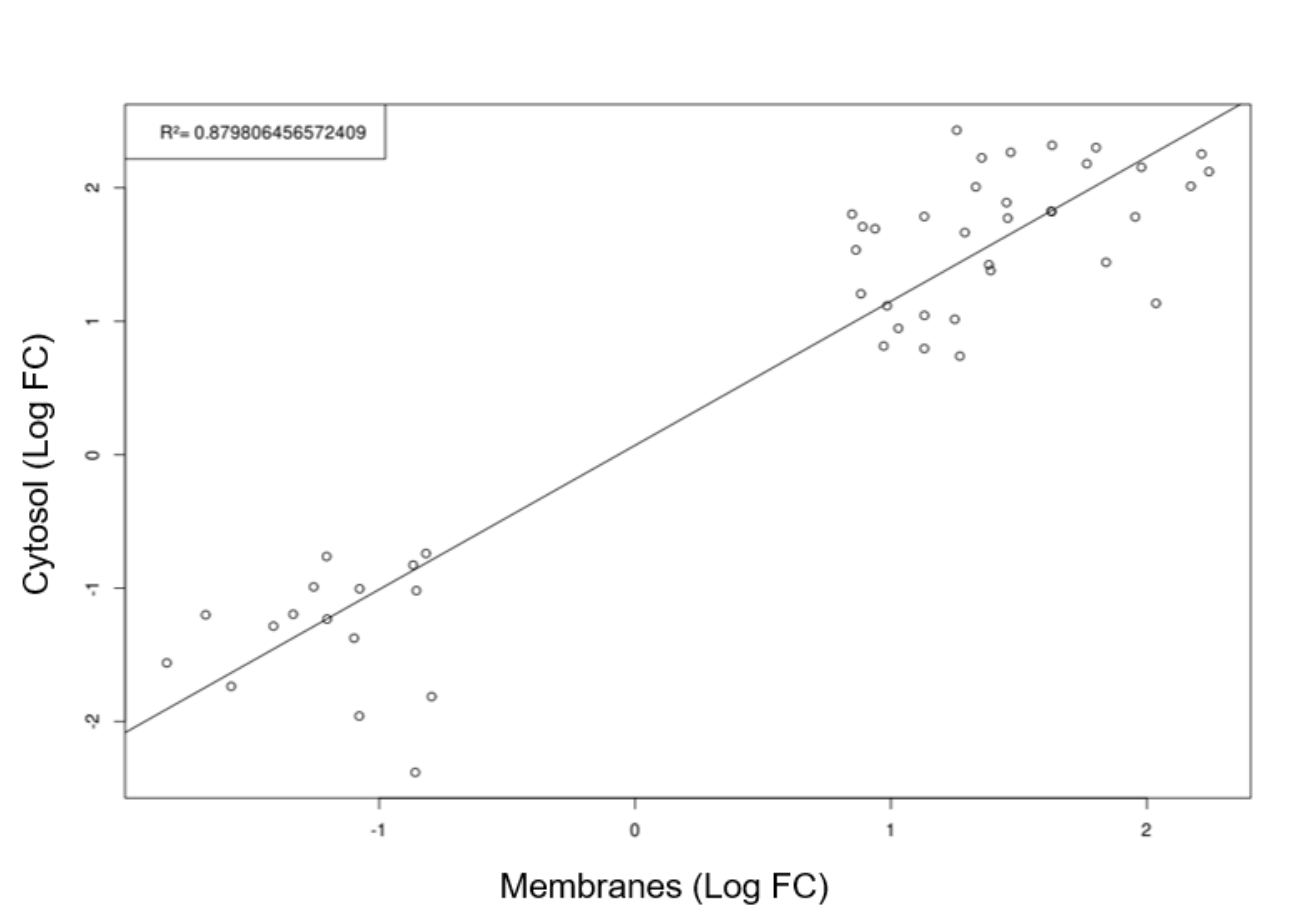

Supplementary Figure 1: Proteins found in common in the membrane and the cytosolic fractions vary in the same direction. Among the 166 identified proteins whose expression significantly changes more than 2 fold, 50 are found in both cytosol-and membrane-enriched fractions. Linear regression analysis between the membrane-fold changes and the cytosolic-fold changes shows a positive correlation for both down-regulated and up-regulated proteins. 


\section{Cytosol}
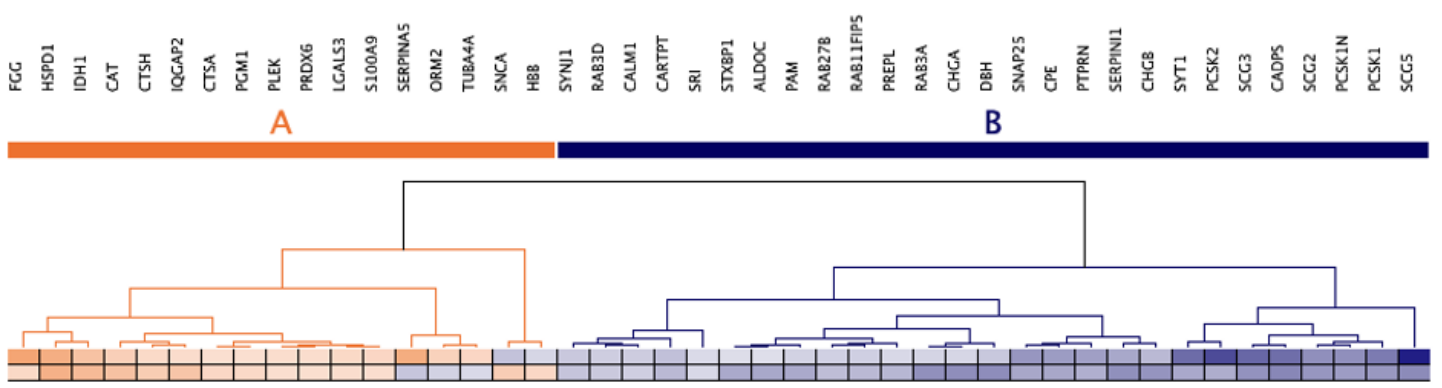

gene expression
protein expression (cytosol)

\section{Membranes}
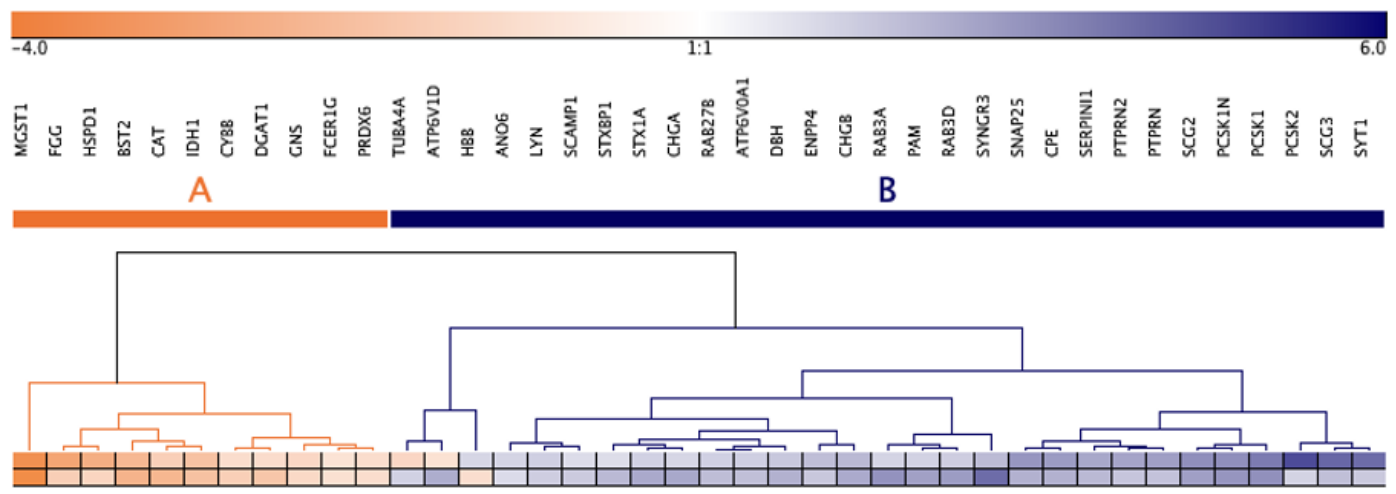

Supplementary Figure 2: Comparison of genes and proteins of the exocytic pathway deregulated in Pheo. The 59 common differentially expressed genes (GSE19422) and proteins (this study) are selected from the exocytosis pathway. Unsupervised hierarchical clustering highlights two clusters of up-and down-regulated genes and proteins. Except for $5(A)$ and $3(B)$ genes/proteins, expression of all the genes (top row) and their proteins (bottom row) varies in the same direction. The color scale illustrates the over- (blue) or under-(red) expression of genes and proteins in Pheo compared to non-tumor tissue. 
bioRxiv preprint doi: https://doi org/10.1101/2021.11.02 466874; this version posted November 5,2021 . The copyright holder for this preprint (which was not certified by peer review) is the author/funder, who has granted bioRxiv a license to display the preprint in perpetuity. It is made available under aCC-BY-NC-ND 4.0 International license.

Supplementary Table 1: Clinical, biochemical, and functional characteristics of the 27 patients with Pheo evaluated in this study.

\begin{tabular}{|c|c|c|c|c|c|c|c|c|c|c|c|c|c|}
\hline$\#$ & Age & Gender & Sym ptom & $\begin{array}{l}\text { Horm onal } \\
\text { hypersecretion } \\
\text { phenotype }\end{array}$ & $\begin{array}{c}\text { Urinary } \\
\text { MN (ULN } \\
\text { ratio) }\end{array}$ & $\begin{array}{l}\text { Urinary } \\
\text { NMN } \\
\text { (ULN } \\
\text { ratio) }\end{array}$ & \begin{tabular}{|c|} 
Plasm a \\
free MN \\
(ULN \\
ratio) \\
\end{tabular} & \begin{tabular}{|c|} 
Plasm a \\
free NMN \\
(ULN \\
ratio) \\
\end{tabular} & $\begin{array}{c}\text { Plasma } \\
\text { CGA } \\
\text { (ULN } \\
\text { ratio) } \\
\end{array}$ & $\begin{array}{l}\text { Size } \\
\text { (cm) }\end{array}$ & $\begin{array}{c}\mid \mathrm{Ki}-67 \\
(\%)\end{array}$ & $\begin{array}{l}\text { PASS } \\
\text { score }\end{array}$ & Genetics \\
\hline 1 & 46 & M & No & $A D$ & 8.1 & 1.2 & - & - & 4.9 & 3.7 & - & 3 & Spor \\
\hline 2 & 54 & $\mathrm{~F}$ & No & $A D$ & 2.1 & 0.9 & 6.0 & 2.0 & 0.5 & 2 & 1 & 0 & NF1 \\
\hline 3 & 50 & M & Yes & $A D$ & 2.8 & 13.5 & 3.1 & 2.0 & 1.5 & 3.5 & - & 1 & NF1 \\
\hline 4 & 34 & M & Yes & NAD & 0.6 & 7.1 & 1.0 & 3.0 & 4.8 & 1.7 & 4 & 1 & SDHD \\
\hline 5 & 75 & $\mathrm{~F}$ & No & $A D$ & 14.1 & 4.7 & - & - & 4.6 & 8.0 & - & 3 & Spor \\
\hline 6 & 61 & M & Yes & NAD & 1.5 & 2.0 & 2.0 & 10.0 & - & 2.5 & - & 3 & Spor \\
\hline 7 & 64 & M & No & $A D$ & 6.5 & 5.5 & 5.3 & 5.0 & - & 4.2 & 1 & 4 & Spor \\
\hline 8 & 43 & $\mathrm{~F}$ & Yes & NAD & 0.4 & 16 & 1.0 & 26.0 & 3.6 & 5.0 & - & 4 & Spor \\
\hline 9 & 30 & $M$ & No & NAD & 0.3 & 6.6 & 0.1 & 4.4 & 3.1 & 5.5 & 3 & 1 & SDHB \\
\hline 10 & 47 & M & Yes & NAD & 1.0 & 8.7 & - & - & - & 4 & - & 2 & - \\
\hline 11 & 47 & $\mathrm{~F}$ & Yes & $A D$ & 38.6 & 3.7 & 3.4 & 2.0 & - & 6.5 & 1 & 6 & NF1 \\
\hline 12 & 58 & M & Yes & $A D$ & 1.9 & 4.6 & - & - & 0.9 & 4.4 & 5 & 0 & - \\
\hline 13 & 36 & $\mathrm{~F}$ & Yes & $A D$ & 6.6 & 7.9 & 10.3 & 10 & 3.4 & 5.0 & 2 & 2 & - \\
\hline 14 & 50 & $M$ & Yes & $A D$ & 18.0 & 5.2 & - & - & - & 7.0 & 1 & 2 & Spor \\
\hline 15 & 42 & M & Yes & NAD & 2.0 & 13.0 & 0.1 & 5.6 & 1.5 & 4.0 & - & 0 & - \\
\hline 16 & 47 & $\mathrm{~F}$ & Yes & NAD & 4.6 & 23.4 & - & - & 1.2 & 7.0 & 1 & 0 & Spor \\
\hline 17 & 58 & $\mathrm{~F}$ & Yes & $A D$ & - & - & 1.9 & 2.5 & - & - & - & 1 & NF1 \\
\hline 18 & 62 & $M$ & Yes & $A D$ & 54.1 & 9.6 & - & - & - & 4.5 & - & 0 & - \\
\hline 19 & 46 & M & Yes & NAD & 0.9 & 12.5 & 0.8 & 8.3 & 10 & 5.0 & - & 3 & RET \\
\hline 20 & 58 & $\mathrm{~F}$ & Yes & $A D$ & 2.8 & 10.3 & 4.4 & 7.4 & - & 3.5 & 1 & 4 & - \\
\hline 21 & 53 & $\mathrm{~F}$ & No & $A D$ & - & - & 2.6 & 1.3 & - & 2.5 & 4 & 4 & Spor \\
\hline 22 & 45 & M & Yes & $A D$ & - & - & 19.9 & 2.2 & - & 4.9 & 1 & 1 & Spor \\
\hline $1 \mathrm{P}$ & 262 & $\bar{F}$ & Yes & NAD & 1.5 & 18.6 & 1.0 & 1.0 & - & 5 & - & - & Spor \\
\hline $2 \mathrm{P}$ & 48 & $\mathrm{~F}$ & Yes & $A D$ & 10 & 5 & - & - & - & 3.5 & - & - & - \\
\hline $3 P$ & 58 & $M$ & Yes & $A D$ & 1.3 & 1.5 & 5.0 & 5.0 & 2.6 & 8.0 & 1 & 0 & Spor \\
\hline $4 \mathrm{P}$ & 52 & $\mathrm{~F}$ & Yes & $A D$ & & & & & 6.3 & 5.0 & 7 & 9 & Spor \\
\hline $6 \mathrm{P}$ & 69 & M & Yes & $A D$ & 2.0 & 2.0 & - & - & - & 3.0 & 2 & 0 & - \\
\hline
\end{tabular}

Age at diagnosis, gender ( $F:$ female, $M:$ male), hormonal hypersecretion symptoms and phenotype, biochemical and functional values are represented for each patient number (\#). AD: adrenergic, NAD: noradrenergic, MN: metanephrine, NMN: normetanephrine, ULN: upper limit normal, CGA: chromogranin A, PASS: Pheochromocytoma of the Adrenal Gland Scaled Score, Spor: sporadic, NF1: Neurofibromatosis type 1, RET: Rearranged during transfection, SDHB: Succinate dehydrogenase B, SDHD: Succinate dehydrogenase D, - : not available. 
bioRxiv preprint doi: https://doi.org/10.1101/2021.11.02.466874; this version posted November $5,2021$. The copyright holder for this preprint (which was not certified by peer review) is the author/funder, who has granted bioRxiv a license to display the preprint in perpetuity. It is made available under aCC-BY-NC-ND 4.0 International license.

\section{Supplementary Table 2: List of up- and down-regulated proteins in Pheo by comparison with the adjacent non-tumor tissue.}

\begin{tabular}{|c|c|c|c|c|c|c|}
\hline Gene & Protein & $\begin{array}{l}\text { Entry (Uni- } \\
\text { ProtKB) }\end{array}$ & Fraction & $\begin{array}{c}\text { Fold } \\
\text { change }\end{array}$ & $\begin{array}{l}\text { adj-p va- } \\
\text { lue }\end{array}$ & Function \\
\hline SYNGR3 & Synaptogyrin-3 & O43761 & Membrane & 17.72 & 0.00018 & $\begin{array}{l}\text { Neurotransmiter uptake, regulation } \\
\text { of dopamine transporter activity }\end{array}$ \\
\hline MMRN1 & Multimerin-1 & Q13201 & Cytosol & 15.94 & 0.00016 & $\begin{array}{l}\text { Protein localized in granules, carrier } \\
\text { protein for platelet factor } \mathrm{V}-\mathrm{Va}\end{array}$ \\
\hline SERPINE2 & Glia-derived nexin & P07093 & Cytosol & 11.29 & 0.00335 & $\begin{array}{l}\text { Secretory granule organization, } \\
\text { granule biogenesis }\end{array}$ \\
\hline CADPS & $\begin{array}{l}\text { Calcium-dependent se- } \\
\text { cretion activator } 1\end{array}$ & Q9ULU8 & Cytosol & 11.25 & 0.00016 & $\begin{array}{l}\text { Priming, calcium binding, plasma } \\
\text { membrane binding, SNARE binding }\end{array}$ \\
\hline SCG5 & $\begin{array}{l}\text { Neuroendocrine protein } \\
7 B 2\end{array}$ & P05408 & Cytosol & 10.59 & 0.00016 & $\begin{array}{l}\text { Secreted, in granules, peptide hor- } \\
\text { mone processing }\end{array}$ \\
\hline $\mathrm{DBH}$ & $\begin{array}{l}\text { Dopamine beta-hydroxy- } \\
\text { lase }\end{array}$ & P09172 & Cytosol & 10.09 & 0.00103 & Dopamine synthesis pathway \\
\hline CHGA & Chromogranin-A & P10645 & Cytosol & 9.92 & 0.00090 & $\begin{array}{l}\text { Granule biogenesis, secretory gran- } \\
\text { ule organization, peptide hormone } \\
\text { processing }\end{array}$ \\
\hline SERPINI1 & Neuroserpin & Q99574 & Cytosol & 9.57 & 0.00103 & $\begin{array}{l}\text { Granule biogenesis, secretory gran- } \\
\text { ule organization, peptide hormone } \\
\text { processing }\end{array}$ \\
\hline RAB3A & $\begin{array}{l}\text { Ras-related protein Rab- } \\
3 \mathrm{~A}\end{array}$ & P20336 & Cytosol & 9.45 & 0.00039 & Vesicle trafficking, docking \\
\hline PCSK1 & $\begin{array}{l}\text { Neuroendocrine conver- } \\
\text { tase } 1\end{array}$ & P29120 & Membrane & 9.36 & 0.00050 & Peptide hormone processing \\
\hline SCG3 & Secretogranin-3 & Q8WXD2 & Cytosol & 9.19 & 0.00040 & $\begin{array}{l}\text { Secreted, in granules, peptide hor- } \\
\text { mone processing }\end{array}$ \\
\hline RAB3A & $\begin{array}{l}\text { Ras-related protein Rab- } \\
3 \mathrm{~A}\end{array}$ & P20336 & Membrane & 9.09 & 0.00043 & Vesicle trafficking, docking \\
\hline CHGB & Secretogranin-1 & P05060 & Cytosol & 8.79 & 0.00036 & $\begin{array}{l}\text { Granule biogenesis, secretory gran- } \\
\text { ule organization, peptide hormone } \\
\text { processing }\end{array}$ \\
\hline PCSK1N & ProSAAS & Q9UHG2 & Membrane & 8.72 & 0.00137 & Peptide hormone processing \\
\hline SCG2 & Secretogranin-2 & P13521 & Cytosol & 8.56 & 0.00034 & $\begin{array}{l}\text { Secreted, in granules, peptide hor- } \\
\text { mone processing }\end{array}$ \\
\hline PCSK1 & $\begin{array}{l}\text { Neuroendocrine conver- } \\
\text { tase } 1\end{array}$ & P29120 & Cytosol & 8.29 & 0.00041 & Peptide hormone processing \\
\hline SV2B & $\begin{array}{l}\text { Synaptic vesicle glyco- } \\
\text { protein } 2 B\end{array}$ & Q7L112 & Membrane & 7.90 & 0.00427 & $\begin{array}{l}\text { Binds synaptotagmin1, synaptotag- } \\
\text { min trafficking, calcium regulator }\end{array}$ \\
\hline RAB3D & $\begin{array}{l}\text { Ras-related protein Rab- } \\
\text { 3D }\end{array}$ & O95716 & Membrane & 7.61 & 0.00059 & Vesicle trafficking, docking \\
\hline PCSK1N & ProSAAS & Q9UHG2 & Cytosol & 7.44 & 0.00087 & Peptide hormone processing \\
\hline GAL & Galanin peptides & P22466 & Cytosol & 7.39 & 0.00413 & $\begin{array}{l}\text { Inhibits exocytosis, peptide hormone } \\
\text { processing }\end{array}$ \\
\hline SCG2 & Secretogranin-2 & P13521 & Membrane & 7.19 & 0.00075 & $\begin{array}{l}\text { Secreted, in granules, peptide hor- } \\
\text { mone processing }\end{array}$ \\
\hline PAM & $\begin{array}{l}\text { Peptidyl-glycine alpha- } \\
\text { amidating monooxygen- } \\
\text { ase }\end{array}$ & P19021 & Membrane & 7.02 & 0.00049 & $\begin{array}{l}\text { Secretory granule transmembrane } \\
\text { protein, fatty acid biosynthetic pro- } \\
\text { cess }\end{array}$ \\
\hline PSAP & Prosaposin & P07602 & Cytosol & 6.63 & 0.00174 & $\begin{array}{l}\text { Lysosomal protein, lipid binding, } \\
\text { GM1 binding }\end{array}$ \\
\hline SYTL4 & $\begin{array}{l}\text { Synaptotagmin-like pro- } \\
\text { tein } 4\end{array}$ & Q96C24 & Cytosol & 6.58 & 0.00026 & $\begin{array}{l}\text { Priming, calcium binding, plasma } \\
\text { membrane binding, SNARE binding }\end{array}$ \\
\hline NAPB & $\begin{array}{l}\text { Beta-soluble NSF at- } \\
\text { tachment protein }\end{array}$ & Q9H115 & Membrane & 6.26 & 0.00050 & $\begin{array}{l}\text { Recycling, NSF activity, vesicular } \\
\text { transport endosome golgi }\end{array}$ \\
\hline
\end{tabular}


bioRxiv preprint doi: https://doi org/10.1101/2021.11.02.466874; this version posted November 5, 2021. The copyright holder for this preprint (which was not certified by peer review) is the author/funder, who has granted bioRxiv a license to display the preprint in perpetuity. It is made available under aCC-BY-NC-ND 4.0 International license.

\begin{tabular}{|c|c|c|c|c|c|c|}
\hline SNAP25 & $\begin{array}{l}\text { Synaptosomal-asso- } \\
\text { ciated protein } 25\end{array}$ & P60880 & Cytosol & 6.17 & 0.00089 & SNARE, priming \\
\hline CPE & Carboxypeptidase E & P16870 & Cytosol & 6.14 & 0.00145 & Peptide hormone processing \\
\hline ALDOC & $\begin{array}{l}\text { Fructose-bisphosphate } \\
\text { aldolase C }\end{array}$ & P09972 & Cytosol & 6.05 & 0.00090 & $\begin{array}{l}\text { Cytoskeletal binding protein, cata- } \\
\text { lytic activity }\end{array}$ \\
\hline TIMP1 & $\begin{array}{l}\text { Metalloproteinase inhibi- } \\
\text { tor } 1\end{array}$ & P01033 & Cytosol & 6.03 & 0.00271 & $\begin{array}{l}\text { Metalloproteinase inhibitor, peptide } \\
\text { hormone processing, secreted }\end{array}$ \\
\hline CHGA & Chromogranin-A & P10645 & Membrane & 6.02 & 0.00381 & $\begin{array}{l}\text { Granule biogenesis, secretory gran- } \\
\text { ule organization, peptide hormone } \\
\text { processing }\end{array}$ \\
\hline SYT1 & Synaptotagmin-1 & P21579 & Cytosol & 5.93 & 0.00104 & $\begin{array}{l}\text { Priming, calcium binding, plasma } \\
\text { membrane binding, SNARE binding }\end{array}$ \\
\hline PAM & $\begin{array}{l}\text { Peptidyl-glycine alpha- } \\
\text { amidating monooxygen- } \\
\text { ase }\end{array}$ & P19021 & Cytosol & 5.91 & 0.00051 & $\begin{array}{l}\text { Secretory granule transmembrane } \\
\text { protein, fatty acid biosynthetic pro- } \\
\text { cess }\end{array}$ \\
\hline STX1A & Syntaxin-1A & Q16623 & Membrane & 5.88 & 0.00050 & SNARE, priming \\
\hline STXBP1 & $\begin{array}{l}\text { Syntaxin-binding protein } \\
1\end{array}$ & P61764 & Cytosol & 5.85 & 0.00034 & $\begin{array}{l}\text { Priming, fusion, binds SNARE and } \\
\text { Munc13 }\end{array}$ \\
\hline $\mathrm{CHGB}$ & Secretogranin-1 & P05060 & Membrane & 5.81 & 0.00077 & $\begin{array}{l}\text { Granule biogenesis, secretory gran- } \\
\text { ule organization, peptide hormone } \\
\text { processing }\end{array}$ \\
\hline ATP6AP2 & Renin receptor & O75787 & Membrane & 5.80 & 0.00161 & Renin receptor, V-ATPase assembly \\
\hline ATP6V1D & $\begin{array}{l}\text { V-type proton ATPase } \\
\text { subunit D }\end{array}$ & Q9Y5K8 & Membrane & 5.50 & 0.00075 & Vacuaolar ATPase activity \\
\hline CTSZ & Cathepsin-Z & Q9UBR2 & Cytosol & 5.49 & 0.01285 & $\begin{array}{l}\text { Lysosomal protease (unclear role in } \\
\text { exocytosis) }\end{array}$ \\
\hline PCSK2 & $\begin{array}{l}\text { Neuroendocrine conver- } \\
\text { tase } 2\end{array}$ & P16519 & Cytosol & 5.41 & 0.00578 & Peptide hormone processing \\
\hline B2M & Beta-2-microglobulin & P61769 & Cytosol & 5.33 & 0.00089 & $\begin{array}{l}\text { Peptide hormone processing, com- } \\
\text { ponent of the major histocompatibil- } \\
\text { ity complex }\end{array}$ \\
\hline CADPS2 & $\begin{array}{l}\text { Calcium-dependent se- } \\
\text { cretion activator } 2\end{array}$ & Q86UW7 & Cytosol & 5.27 & 0.00041 & $\begin{array}{l}\text { Priming, calcium binding, plasma } \\
\text { membrane binding, SNARE binding }\end{array}$ \\
\hline PTPRN & $\begin{array}{l}\text { Receptor-type tyrosine- } \\
\text { protein phosphatase-like } \\
\mathrm{N}\end{array}$ & Q16849 & Cytosol & 5.26 & 0.00145 & $\begin{array}{l}\text { Regulates number of DCV, DCV } \\
\text { maturation }\end{array}$ \\
\hline PRCP & $\begin{array}{l}\text { Lysosomal Pro-X car- } \\
\text { boxypeptidase }\end{array}$ & P42785 & Cytosol & 5.17 & 0.00290 & Peptide hormone processing \\
\hline $\mathrm{DBH}$ & $\begin{array}{l}\text { Dopamine beta-hydroxy- } \\
\text { lase }\end{array}$ & P09172 & Membrane & 5.08 & 0.00136 & Dopamine synthesis pathway \\
\hline CPE & Carboxypeptidase E & P16870 & Membrane & 5.07 & 0.00239 & Peptide hormone processing \\
\hline SNAP25 & $\begin{array}{l}\text { Synaptosomal-asso- } \\
\text { ciated protein } 25\end{array}$ & P60880 & Membrane & 5.06 & 0.00076 & SNARE, priming \\
\hline RAPGEF4 & $\begin{array}{l}\text { Rap guanine nucleotide } \\
\text { exchange factor } 4\end{array}$ & Q8WZA2 & Cytosol & 5.03 & 0.00115 & $\begin{array}{l}\text { Interacts with RIM2, cAMP depend- } \\
\text { ent-PKA independant exocytosis, } \\
\text { GEF of RAP 1-3 }\end{array}$ \\
\hline NFASC & Neurofascin & 094856 & Membrane & 4.85 & 0.00069 & $\begin{array}{l}\text { Adhesion, spectrin-organisa- } \\
\text { tion,plasma membrane localization }\end{array}$ \\
\hline ECM1 & $\begin{array}{l}\text { Extracellular matrix pro- } \\
\text { tein } 1\end{array}$ & Q16610 & Cytosol & 4.70 & 0.00639 & Platelet degranulation \\
\hline
\end{tabular}


bioRxiv preprint doi: https://doi.org/10.1101/2021.11.02.466874; this version posted November $5,2021$. The copyright holder for this preprint (which was not certified by peer review) is the author/funder, who has granted bioRxiv a license to display the preprint in perpetuity. It is made available under aCC-BY-NC-ND 4.0 International license.

Ras-related protein Rab27A

P51159

Cytosol

4.62

0.00231

\begin{tabular}{|llllll|}
\hline CST3 & Cystatin-C & P01034 & Cytosol & 4.58 & 0.00315 \\
\hline SYT2 & Synaptotagmin-2 & Q8N9I0 & Membrane & 4.56 & 0.01268
\end{tabular}

CD44

CD44 antigen

P16070

Membrane

4.55

0.00066

$\begin{array}{ll}\text { PREPL } & \begin{array}{l}\text { Prolyl endopeptidase } \\ \text { like }\end{array}\end{array}$

Q4J6C6

Cytosol

4.52

0.00075

$\begin{array}{ll}\text { SMPDingomyelin phospho } & \text { Spherase } \\ \text { diesteras }\end{array}$

P17405

Cytosol

4.46

0.00089

CD63 CD63 antigen

P08962

Membrane

4.41

0.00198

RAB11FIP5

Rab11 family-interacting protein 5

Q9BXF6

Cytosol

4.34

0.00340

Cocaine- and ampheta-

CARTPT mine-regulated transcript protein

Q16568 Cytosol $\quad 4.33$

0.00924 $\begin{array}{lll}\text { Membrane } \quad 4.32 & 0.00137\end{array}$

SERPINI1 Neuroserpi

$\begin{array}{ll}\text { QPCT } & \begin{array}{l}\text { Glutaminyl-peptide cy- } \\ \text { clotransferase }\end{array} \\ \text { STXBP1 } & \begin{array}{l}\text { Syntaxin-binding protein } \\ 1\end{array} \\ \text { SYTL4 } & \begin{array}{l}\text { Synaptotagmin-like pro- } \\ \text { tein } 4\end{array} \\ \text { NAPB } & \begin{array}{l}\text { Beta-soluble NSF at- } \\ \text { tachment protein }\end{array}\end{array}$

$\begin{array}{ll}\text { ATP8A1 } & \text { Phospholipid-transpor- } \\ \text { ting ATPase IA }\end{array}$

$\begin{array}{ll}\text { RAB3B } & \text { Ras-related protein Rab- } \\ \text { 3B }\end{array}$

\begin{tabular}{|c|c|c|c|c|c|}
\hline SYNGR1 & Synaptogyrin-1 & O43759 & Membrane & 4.02 & 0.00286 \\
\hline RAB27B & $\begin{array}{l}\text { Ras-related protein Rab- } \\
27 B\end{array}$ & O00194 & Membrane & 4.00 & 0.00136 \\
\hline RAB3B & $\begin{array}{l}\text { Ras-related protein Rab- } \\
\text { 3B }\end{array}$ & P20337 & Membrane & 3.97 & 0.00233 \\
\hline
\end{tabular}

Q16769 Membrane $\quad 4.27 \quad 0.03997$

$\begin{array}{llll}\text { P61764 Membrane } & 4.27 & 0.00113\end{array}$

$\begin{array}{llll}\text { Q96C24 Membrane } & 4.25 & 0.00095\end{array}$

$\begin{array}{llll}\mathrm{Q} 9 \mathrm{H} 115 & \text { Cytosol } & 4.21 & 0.00194\end{array}$

Q9Y2Q0

Membrane

4.20

0.00076

$\begin{array}{llll}\text { P20337 Cytosol } & 4.13 & 0.01969\end{array}$

\begin{tabular}{|c|c|c|c|c|c|}
\hline RAB27B & $\begin{array}{l}\text { Ras-related protein Rab- } \\
\text { 27B }\end{array}$ & O00194 & Cytosol & 3.96 & 0.00067 \\
\hline SRP14 & $\begin{array}{l}\text { Signal recognition par- } \\
\text { ticle } 14 \mathrm{kDa} \text { protein }\end{array}$ & P37108 & Cytosol & 3.92 & 0.00141 \\
\hline
\end{tabular}

\section{SYT7} Synaptotagmin-7

043581

Membrane

3.88
Interacts with granuphilin to regulate exocytosis, GTPase, docking, priming, DCV maturation, regulates endocytic pathway

Neutrophil degranulation (unclear role in exocytosis)

Priming, calcium binding, plasma membrane binding, SNARE binding Transmembrane protein, assembles via its cytoplasmic domain a protein complex including RhoA, Rac1, $\mathrm{RHO}-\mathrm{K}$ and PLC, calcium mobilization, actin reorganization PMSF regulation, synaptic vesicle exocytosis

Lipid reorganization of the plasma membrane, acid sphingomyelin phosphodiesterase activity Reorganization of actin cytoskeleton, vesicular transport Protein trafficking from endosomes to plasma membrane, Rab effector, regulates $\mathrm{V}$-ATPase

Regulates insulin secretion and production, no mechanism known

Granule biogenesis, secretory granule organization, peptide hormone processing

Neutrophil degranulation (unclear role in exocytosis)

Priming, fusion, binds SNARE and Munc13

Priming, calcium binding, plasma membrane binding, SNARE binding Recycling, NSF activity, Vesicular transport endosome golgi

Lipid reorganization of the plasma membrane, flippase, P4-ATPase

Vesicle trafficking, GTPase, vesicle biogenesis, priming

Synaptic vesicle protein, inhibits exocytosis

GTPase, docking, priming

Vesicle trafficking, GTPase, vesicle biogenesis, priming

GTPase, docking, priming

Secretory granule lumen (unclear role in exocytosis)

Priming, calcium binding, plasma membrane binding, SNARE binding 
bioRxiv preprint doi: https://doi.org/10.1101/2021.11.02.466874; this version posted November 5,2021 . The copyright holder for this preprint (which was not certified by peer review) is the author/funder, who has granted bioRxiv a license to display the preprint in perpetuity. It is made available under aCC-BY-NC-ND 4.0 International license.

\begin{tabular}{|c|c|c|c|c|c|c|}
\hline ATP6V0A1 & $\begin{array}{l}\text { V-type proton ATPase } \\
116 \mathrm{kDa} \text { subunit a1 }\end{array}$ & Q93050 & Membrane & 3.87 & 0.00135 & $\begin{array}{l}\text { Vacuaolar ATPase activity, vesicle } \\
\text { acidification }\end{array}$ \\
\hline SCG3 & Secretogranin-3 & Q8WXD2 & Membrane & 3.86 & 0.00331 & $\begin{array}{l}\text { Secreted, in granules, peptide hor- } \\
\text { mone processing }\end{array}$ \\
\hline GAL & Galanin peptides & P22466 & Membrane & 3.77 & 0.03071 & $\begin{array}{l}\text { Inhibits exocytosis, peptide hormone } \\
\text { processing }\end{array}$ \\
\hline PTPRN & $\begin{array}{l}\text { Receptor-type tyrosine- } \\
\text { protein phosphatase-like } \\
\mathrm{N}\end{array}$ & Q16849 & Membrane & 3.61 & 0.00305 & $\begin{array}{l}\text { Regulates number of DCV, DCV } \\
\text { maturation }\end{array}$ \\
\hline AMPD3 & AMP deaminase 3 & Q01432 & Cytosol & 3.59 & 0.00320 & $\begin{array}{l}\text { Energy metabolism (unclear role in } \\
\text { exocytosis) }\end{array}$ \\
\hline RAB4A & $\begin{array}{l}\text { Ras-related protein Rab- } \\
4 \mathrm{~A}\end{array}$ & P20338 & Cytosol & 3.58 & 0.00149 & Vesicle trafficking, docking, priming \\
\hline DNM1L & Dynamin-1-like protein & 000429 & Membrane & 3.55 & 0.00137 & GTPase, endocytosis, fusion \\
\hline SERPINE2 & Glia-derived nexin & P07093 & Membrane & 3.50 & 0.00662 & $\begin{array}{l}\text { Secretory granule organization, } \\
\text { granule biogenesis }\end{array}$ \\
\hline SYNJ1 & Synaptojanin-1 & O43426 & Cytosol & 3.49 & 0.00399 & $\begin{array}{l}\text { Regulation of lipid composition of the } \\
\text { plasma membrane, endocytosis }\end{array}$ \\
\hline TOLLIP & Toll-interacting protein & Q9H0E2 & Membrane & 3.47 & 0.00204 & $\begin{array}{l}\text { Autophagy, ubiquitin dependent pro- } \\
\text { cess (unclear role in exocytosis) }\end{array}$ \\
\hline PTPRN2 & $\begin{array}{l}\text { Receptor-type tyrosine- } \\
\text { protein phosphatase N2 }\end{array}$ & Q92932 & Membrane & 3.38 & 0.00137 & $\begin{array}{l}\text { Regulates number of DCV, DCV } \\
\text { maturation, lipid reorganization }\end{array}$ \\
\hline SERPINA5 & $\begin{array}{l}\text { Plasma serine protease } \\
\text { inhibitor }\end{array}$ & P05154 & Cytosol & 3.36 & 0.01310 & Secreted \\
\hline PFN2 & Profilin-2 & P35080 & Cytosol & 3.33 & 0.00163 & $\begin{array}{l}\text { Actin reorganization, binds PIP2, In- } \\
\text { hibits PIP2 hydrolysis }\end{array}$ \\
\hline ENPP4 & $\begin{array}{l}\text { Bis(5'-adenosyl)-triphos- } \\
\text { phatase ENPP4 }\end{array}$ & Q9Y6X5 & Membrane & 3.24 & 0.00449 & Unclear role in exocytosis \\
\hline ALDOA & $\begin{array}{l}\text { Fructose-bisphosphate } \\
\text { aldolase A }\end{array}$ & P04075 & Cytosol & 3.22 & 0.00584 & $\begin{array}{l}\text { Glycogenesis, scaffold protein, se- } \\
\text { creted }\end{array}$ \\
\hline TUBB4B & Tubulin beta-4B chain & P68371 & Membrane & 3.16 & 0.00164 & $\begin{array}{l}\text { Microtubules component, cytoskele- } \\
\text { tal protein }\end{array}$ \\
\hline RAB3D & $\begin{array}{l}\text { Ras-related protein Rab- } \\
\text { 3D }\end{array}$ & O95716 & Cytosol & 3.10 & 0.00301 & Vesicle trafficking, docking, priming \\
\hline DYNC1H1 & $\begin{array}{l}\text { Cytoplasmic dynein } 1 \\
\text { heavy chain } 1\end{array}$ & Q14204 & Membrane & 3.09 & 0.00201 & Vesicle transporter, ATPase \\
\hline TUBB & Tubulin beta chain & P07437 & Membrane & 3.09 & 0.00243 & $\begin{array}{l}\text { Microtubules component, cytoskele- } \\
\text { tal protein }\end{array}$ \\
\hline SYT1 & Synaptotagmin-1 & P21579 & Membrane & 3.08 & 0.00386 & $\begin{array}{l}\text { Priming, calcium binding, plasma } \\
\text { membrane binding, SNARE binding }\end{array}$ \\
\hline SCAMP1 & $\begin{array}{l}\text { Secretory carrier-associ- } \\
\text { ated membrane protein } \\
1\end{array}$ & 015126 & Membrane & 3.08 & 0.00388 & $\begin{array}{l}\text { Present at docking, priming sites, } \\
\text { role in exocytosis }\end{array}$ \\
\hline DYNC1LI1 & $\begin{array}{l}\text { Cytoplasmic dynein } 1 \\
\text { light intermediate chain } \\
1\end{array}$ & Q9Y6G9 & Membrane & 3.07 & 0.00220 & Vesicle transporter, ATPase \\
\hline APP & $\begin{array}{l}\text { Amyloid-beta precursor } \\
\text { protein }\end{array}$ & P05067 & Cytosol & 3.04 & 0.00251 & $\begin{array}{l}\text { Interacts with synaptic release ma- } \\
\text { chinery, facilitate transmitters re- } \\
\text { lease }\end{array}$ \\
\hline TOM1 & Target of Myb protein 1 & O60784 & Cytosol & 2.98 & 0.00293 & $\begin{array}{l}\text { Priming, negatively regulates exocy- } \\
\text { tosis }\end{array}$ \\
\hline CD9 & CD9 antigen & P21926 & Membrane & 2.95 & 0.00831 & Cell adhesion, Fusion \\
\hline
\end{tabular}


bioRxiv preprint doi: https://doi.org/10.1101/2021.11.02.466874; this version posted November 5, 2021. The copyright holder for this preprint (which was not certified by peer review) is the author/funder, who has granted bioRxiv a license to display the preprint in perpetuity. It is made available under aCC-BY-NC-ND 4.0 International license.

\begin{tabular}{|c|c|c|c|c|c|c|}
\hline $\mathrm{RPH} 3 \mathrm{~A}$ & Rabphilin-3A & Q9Y2J0 & Membrane & 2.93 & 0.03797 & Docking, fusion, priming \\
\hline РPP3СB & $\begin{array}{l}\text { Serine/threonine-protein } \\
\text { phosphatase } 2 \mathrm{~B} \text { cata- } \\
\text { lytic subunit beta isoform }\end{array}$ & P16298 & Cytosol & 2.87 & 0.00228 & $\begin{array}{l}\text { Protein phosphatase (unclear role in } \\
\text { exocytosis) }\end{array}$ \\
\hline LYN & $\begin{array}{l}\text { Tyrosine-protein kinase } \\
\text { Lyn }\end{array}$ & P07948 & Membrane & 2.87 & 0.00386 & $\begin{array}{l}\text { Tyrosine protein kinase (unclear role } \\
\text { in exocytosis) }\end{array}$ \\
\hline DYNC1H1 & $\begin{array}{l}\text { Cytoplasmic dynein } 1 \\
\text { light intermediate chain } \\
1\end{array}$ & Q9Y6G9 & Cytosol & 2.83 & 0.00233 & Vesicle transporter, ATPase \\
\hline CALM1 & Calmodulin-1 & P0DP23 & Cytosol & 2.82 & 0.00301 & Priming, fusion, vesicle trafficking \\
\hline VAMP3 & $\begin{array}{l}\text { Vesicle-associated } \\
\text { membrane protein } 3\end{array}$ & Q15836 & Membrane & 2.80 & 0.00332 & $\begin{array}{l}\text { SNARE, involved in vesicular } \\
\text { transport from late endosomes to } \\
\text { TGN }\end{array}$ \\
\hline SDF4 & $\begin{array}{l}45 \mathrm{kDa} \text { calcium-binding } \\
\text { protein }\end{array}$ & Q9BRK5 & Membrane & 2.79 & 0.01404 & $\begin{array}{l}\text { Involved in exocytosis of zymogens } \\
\text { by pancreatic acini }\end{array}$ \\
\hline MYO5A & $\begin{array}{l}\text { Unconventional myosin- } \\
\text { Va }\end{array}$ & Q9Y4I1 & Membrane & 2.76 & 0.00731 & $\begin{array}{l}\text { Actin motor, vesicle transport, cyto- } \\
\text { skeleton }\end{array}$ \\
\hline TOLLIP & Toll-interacting protein & Q9H0E2 & Cytosol & 2.75 & 0.00446 & $\begin{array}{l}\text { Autophagy, ubiquitin dependent pro- } \\
\text { cess (unclear role in exocytosis) }\end{array}$ \\
\hline SNAPIN & $\begin{array}{l}\text { SNARE-associated pro- } \\
\text { tein Snapin }\end{array}$ & 095295 & Cytosol & 2.72 & 0.00307 & $\begin{array}{l}\text { Vesicle trafficking, priming, fusion, } \\
\text { interacts with SNAREs }\end{array}$ \\
\hline APP & $\begin{array}{l}\text { Amyloid-beta precursor } \\
\text { protein }\end{array}$ & P05067 & Membrane & 2.67 & 0.00311 & $\begin{array}{l}\text { Interacts with synaptic release ma- } \\
\text { chinery, facilitate transmitters re- } \\
\text { lease }\end{array}$ \\
\hline GARS & Glycine--tRNA ligase & P41250 & Cytosol & 2.65 & 0.00332 & Unclear role in exocytosis \\
\hline TUBA4A & Tubulin alpha- $4 \mathrm{~A}$ chain & P68366 & Membrane & 2.63 & 0.01056 & $\begin{array}{l}\text { Microtubules component, cytoskele- } \\
\text { tal protein }\end{array}$ \\
\hline CLU & Clusterin & P10909 & Membrane & 2.61 & 0.00736 & Secreted \\
\hline ORM2 & $\begin{array}{l}\text { Alpha-1-acid glycopro- } \\
\text { tein } 2\end{array}$ & P19652 & Cytosol & 2.58 & 0.00440 & $\begin{array}{l}\text { Lipid reorganization, actin reorgani- } \\
\text { zation, endocytosis }\end{array}$ \\
\hline SDF4 & $\begin{array}{l}45 \mathrm{kDa} \text { calcium-binding } \\
\text { protein }\end{array}$ & Q9BRK5 & Cytosol & 2.57 & 0.00877 & $\begin{array}{l}\text { Involved in exocytosis of zymogens } \\
\text { by pancreatic acini }\end{array}$ \\
\hline PCSK2 & $\begin{array}{l}\text { Neuroendocrine conver- } \\
\text { tase } 2\end{array}$ & P16519 & Membrane & 2.55 & 0.02773 & Peptide hormone processing \\
\hline FAM3C & Protein FAM3C & Q92520 & Membrane & 2.52 & 0.01201 & $\begin{array}{l}\text { Interacts with SNAP23 and RalA } \\
\text { (unclear role in exocytosis) }\end{array}$ \\
\hline SERPINF2 & Alpha-2-antiplasmin & P08697 & Cytosol & 2.48 & 0.00378 & $\begin{array}{l}\text { Secretory granule organization, } \\
\text { granule biogenesis }\end{array}$ \\
\hline DBNL & Drebrin-like protein & Q9UJU6 & Membrane & 2.48 & 0.00462 & $\begin{array}{l}\text { Binds actin and dynamin-1, actin } \\
\text { polymerization, endocytosis }\end{array}$ \\
\hline CTSZ & Cathepsin-Z & Q9UBR2 & Membrane & 2.43 & 0.01022 & $\begin{array}{l}\text { Lysosomal protease (unclear role in } \\
\text { exocytosis) }\end{array}$ \\
\hline DNAJC3 & $\begin{array}{l}\text { DnaJ homolog subfamily } \\
\text { C member } 3\end{array}$ & Q13217 & Membrane & 2.41 & 0.00880 & Unclear role in exocytosis \\
\hline PFN2 & Profilin-2 & P35080 & Membrane & 2.41 & 0.00569 & $\begin{array}{l}\text { Actin reorganization, binds PIP2, In- } \\
\text { hibits PIP2 hydrolysis }\end{array}$ \\
\hline VAT1 & $\begin{array}{l}\text { Synaptic vesicle mem- } \\
\text { brane protein VAT-1 ho- } \\
\text { molog }\end{array}$ & Q99536 & Cytosol & 2.37 & 0.01795 & $\begin{array}{l}\text { Vesicle protein, calcium binding (un- } \\
\text { clear role in exocytosis) }\end{array}$ \\
\hline RAB27A & $\begin{array}{l}\text { Ras-related protein Rab- } \\
27 \mathrm{~A}\end{array}$ & P51159 & Membrane & 2.36 & 0.01470 & $\begin{array}{l}\text { Interacts with granuphilin to regulate } \\
\text { exocytosis, GTPase, docking, prim- } \\
\text { ing, DCV maturation, regulates en- } \\
\text { docytic pathway }\end{array}$ \\
\hline
\end{tabular}


bioRxiv preprint doi: https://doi.org/10.1101/2021.11.02.466874; this version posted November 5, 2021. The copyright holder for this preprint (which was not certified by peer review) is the author/funder, who has granted bioRxiv a license to display the preprint in perpetuity. It is made available under aCC-BY-NC-ND 4.0 International license.

\begin{tabular}{|c|c|c|c|c|c|c|}
\hline RAB3GAP1 & $\begin{array}{l}\text { Rab3 GTPase-activating } \\
\text { protein catalytic subunit }\end{array}$ & Q15042 & Cytosol & 2.36 & 0.01642 & Vesicle trafficking, docking \\
\hline PFKL & $\begin{array}{l}\text { ATP-dependent 6-phos- } \\
\text { phofructokinase, liver } \\
\text { type }\end{array}$ & P17858 & Cytosol & 2.33 & 0.01501 & Unclear role in exocytosis \\
\hline TIMP1 & $\begin{array}{l}\text { Metalloproteinase inhibi- } \\
\text { tor } 1\end{array}$ & P01033 & Membrane & 2.33 & 0.04521 & $\begin{array}{l}\text { Metalloproteinase inhibitor, peptide } \\
\text { hormone processing, secreted }\end{array}$ \\
\hline SRI & Sorcin & P30626 & Cytosol & 2.29 & 0.01565 & Calcium binding protein, lipid rafts \\
\hline SEPT5 & Septin-5 & Q99719 & Cytosol & 2.27 & 0.00802 & $\begin{array}{l}\text { GTPase, cytoskeleton reorganiza- } \\
\text { tion }\end{array}$ \\
\hline LGALS3BP & $\begin{array}{l}\text { Galectin-3-binding pro- } \\
\text { tein }\end{array}$ & Q08380 & Cytosol & 2.25 & 0.01028 & Unclear role in exocytosis \\
\hline TUBA4A & Tubulin alpha- $4 \mathrm{~A}$ chain & P68366 & Cytosol & 2.25 & 0.02017 & $\begin{array}{l}\text { Microtubules component, cytoskele- } \\
\text { tal protein }\end{array}$ \\
\hline MIF & $\begin{array}{l}\text { Macrophage migration } \\
\text { inhibitory factor }\end{array}$ & P14174 & Cytosol & 2.24 & 0.02151 & Cytokin, secreted \\
\hline TUBB & Tubulin beta chain & P07437 & Cytosol & 2.21 & 0.01572 & $\begin{array}{l}\text { Microtubules component, cytoskele- } \\
\text { tal protein }\end{array}$ \\
\hline ENDOD1 & $\begin{array}{l}\text { Endonuclease domain- } \\
\text { containing } 1 \text { protein }\end{array}$ & 094919 & Membrane & 2.20 & 0.01953 & Unclear role in exocytosis \\
\hline PNP & $\begin{array}{l}\text { Purine nucleoside phos- } \\
\text { phorylase }\end{array}$ & P00491 & Cytosol & 2.20 & 0.01009 & $\begin{array}{l}\text { Unclear role in exocytosis, maybe } \\
\text { secreted }\end{array}$ \\
\hline ACTR1B & Beta-centractin & P42025 & Membrane & 2.17 & 0.01056 & $\begin{array}{l}\text { Cytoskeletal organization, microtu- } \\
\text { bules }\end{array}$ \\
\hline ANO6 & Anoctamin-6 & Q4KMQ2 & Membrane & 2.17 & 0.01947 & $\begin{array}{l}\text { Phospholipid scrambling, lipid reor- } \\
\text { ganization of the plasma membrane }\end{array}$ \\
\hline TRAPPC1 & $\begin{array}{l}\text { Trafficking protein par- } \\
\text { ticle complex subunit } 1\end{array}$ & Q9Y5R8 & Cytosol & 2.16 & 0.04291 & Vesicular transport ER to Golgi \\
\hline AP2A2 & $\begin{array}{l}\text { AP-2 complex subunit } \\
\text { alpha-2 }\end{array}$ & 094973 & Membrane & 2.10 & 0.01217 & Endocytosis, protein transport \\
\hline DNM1L & Dynamin-1-like protein & O00429 & Cytosol & 2.09 & 0.01299 & GTPase, endocytosis, fusion \\
\hline MAN2B1 & $\begin{array}{l}\text { Lysosomal alpha-man- } \\
\text { nosidase }\end{array}$ & O00754 & Cytosol & 2.01 & 0.01332 & Unclear role in exocytosis \\
\hline A2M & Alpha-2-macroglobulin & P01023 & Cytosol & -2.03 & 0.01478 & Unclear role in exocytosis \\
\hline STXBP3 & $\begin{array}{l}\text { Syntaxin-binding protein } \\
3\end{array}$ & O00186 & Membrane & -2.06 & 0.01323 & Docking, fusion, priming \\
\hline APRT & $\begin{array}{l}\text { Adenine phosphoribosyl- } \\
\text { transferase }\end{array}$ & P07741 & Cytosol & -2.06 & 0.01507 & Unclear role in exocytosis \\
\hline DERA & $\begin{array}{l}\text { Deoxyribose-phosphate } \\
\text { aldolase }\end{array}$ & Q9Y315 & Membrane & -2.07 & 0.02014 & Unclear role in exocytosis \\
\hline VAPA & $\begin{array}{l}\text { Vesicle-associated } \\
\text { membrane protein-asso- } \\
\text { ciated protein A }\end{array}$ & Q9P0LO & Membrane & -2.08 & 0.02654 & Vesicle trafficking \\
\hline FGA & Fibrinogen alpha chain & P02671 & Cytosol & -2.09 & 0.03711 & Unclear role in exocytosis \\
\hline PTGES2 & $\begin{array}{l}\text { Prostaglandin E syn- } \\
\text { thase } 2\end{array}$ & Q9H7Z7 & Cytosol & -2.14 & 0.00915 & $\begin{array}{l}\text { Receptor coupled to G proteine Gi, } \\
\text { AMPc (unclear role in exocytosis) }\end{array}$ \\
\hline VCL & Vinculin & P18206 & Cytosol & -2.15 & 0.01566 & $\begin{array}{l}\text { Actin filament binding protein, cyto- } \\
\text { skeletal reorganization }\end{array}$ \\
\hline
\end{tabular}


bioRxiv preprint doi: https://doi.org/10.1101/2021.11.02.466874; this version posted November 5, 2021. The copyright holder for this preprint (which was not certified by peer review) is the author/funder, who has granted bioRxiv a license to display the preprint in perpetuity. It is made available under aCC-BY-NC-ND 4.0 International license.

\begin{tabular}{|c|c|c|c|c|c|c|}
\hline THBS1 & Thrombospondin-1 & P07996 & Cytosol & -2.16 & 0.02546 & Secreted \\
\hline SCCPDH & $\begin{array}{l}\text { Saccharopine dehydro- } \\
\text { genase-like oxidore- } \\
\text { ductase }\end{array}$ & Q8NBX0 & Membrane & -2.21 & 0.01198 & Unclear role in exocytosis \\
\hline ANXA2 & Annexin A2 & P07355 & Membrane & -2.23 & 0.02400 & $\begin{array}{l}\text { Calcium binding protein, lipid bind- } \\
\text { ing, cytoskeletal reorganization, lipid } \\
\text { microdomains }\end{array}$ \\
\hline FCER1G & $\begin{array}{l}\text { High affinity immuno- } \\
\text { globulin epsilon receptor } \\
\text { subunit gamma }\end{array}$ & P30273 & Membrane & -2.23 & 0.00763 & Unclear role in exocytosis \\
\hline FGA & Fibrinogen alpha chain & P02671 & Membrane & -2.26 & 0.02179 & Unclear role in exocytosis \\
\hline PRDX6 & Peroxiredoxin-6 & P30041 & Cytosol & -2.28 & 0.00786 & $\begin{array}{l}\text { Phospholipase, phospholipids reor- } \\
\text { ganization, secreted }\end{array}$ \\
\hline PLEK & Pleckstrin & P08567 & Cytosol & -2.29 & 0.03768 & $\begin{array}{l}\text { PKC target, phosphoinositide bind- } \\
\text { ing, lipid binding }\end{array}$ \\
\hline HBB & Hemoglobin subunit beta & P68871 & Membrane & -2.34 & 0.01042 & Unclear role in exocytosis \\
\hline S100A9 & Protein S100-A9 & P06702 & Cytosol & -2.35 & 0.00924 & $\begin{array}{l}\text { Calcium and zinc binding, degranu- } \\
\text { lation neurtrophil by MAPK depend- } \\
\text { ent mechanism, modulation microtu- } \\
\text { bule cytoskeleton, secreted }\end{array}$ \\
\hline PROS1 & $\begin{array}{l}\text { Vitamin K-dependent } \\
\text { protein S }\end{array}$ & P07225 & Membrane & -2.36 & 0.03700 & $\begin{array}{l}\text { Calcium binding (unclear role in exo- } \\
\text { cytosis) }\end{array}$ \\
\hline SLIRP & $\begin{array}{l}\text { SRA stem-loop-interact- } \\
\text { ing RNA-binding protein, } \\
\text { mitochondrial }\end{array}$ & Q9GZT3 & Cytosol & -2.37 & 0.02528 & Unclear role in exocytosis \\
\hline PRDX6 & Peroxiredoxin-6 & P30041 & Membrane & -2.37 & 0.00880 & $\begin{array}{l}\text { Phospholipase, phospholipids reor- } \\
\text { ganization, secreted }\end{array}$ \\
\hline LGALS3 & Galectin-3 & P17931 & Cytosol & -2.40 & 0.01781 & Unclear role in exocytosis \\
\hline NIT2 & Omega-amidase NIT2 & Q9NQR4 & Cytosol & -2.43 & 0.00548 & Secreted (unclear role in exocytosis) \\
\hline ELANE & Neutrophil elastase & P08246 & Membrane & -2.43 & 0.02242 & Secreted (unclear role in exocytosis) \\
\hline CYBA & $\begin{array}{l}\text { Cytochrome b-245 light } \\
\text { chain }\end{array}$ & P13498 & Membrane & -2.48 & 0.02766 & Unclear role in exocytosis \\
\hline STOM & Stomatin & P27105 & Membrane & -2.52 & 0.00533 & $\begin{array}{l}\text { Lipid raft component, scaffold pro- } \\
\text { tein }\end{array}$ \\
\hline RNPEP & Aminopeptidase B & Q9H4A4 & Cytosol & -2.54 & 0.00389 & $\begin{array}{l}\text { Peptidase (unclear role in exocyto- } \\
\text { sis) }\end{array}$ \\
\hline GLA & Alpha-galactosidase $\mathrm{A}$ & P06280 & Cytosol & -2.59 & 0.03945 & $\begin{array}{l}\text { Glycosphyngolipid hydrolisis, lipid } \\
\text { reorganization, lipid degradation in } \\
\text { lysosome, glycoprotein }\end{array}$ \\
\hline S100A13 & Protein S100-A13 & Q99584 & Membrane & -2.60 & 0.04494 & $\begin{array}{l}\text { Calcium binding, binds phosphatidyl- } \\
\text { serine, lipid binding, secreted, regu- } \\
\text { late FGF-1 secretion }\end{array}$ \\
\hline PGM1 & Phosphoglucomutase-1 & P36871 & Cytosol & -2.64 & 0.00315 & $\begin{array}{l}\text { Glucose synthesis and catalysis } \\
\text { pathway, secreted }\end{array}$ \\
\hline LAMTOR1 & $\begin{array}{l}\text { Ragulator complex pro- } \\
\text { tein LAMTOR1 }\end{array}$ & Q6IAA8 & Cytosol & -2.65 & 0.00603 & $\begin{array}{l}\text { mTor pathway, activated by amino- } \\
\text { acids, anchoring regulator complex } \\
\text { to membranes, may play a role in } \\
\text { RhoA activation, lysosomal exocyto- } \\
\text { sis }\end{array}$ \\
\hline
\end{tabular}


bioRxiv preprint doi: https://doi.org/10.1101/2021.11.02.466874; this version posted November 5, 2021. The copyright holder for this preprint (which was not certified by peer review) is the author/funder, who has granted bioRxiv a license to display the preprint in perpetuity. It is made available under aCC-BY-NC-ND 4.0 International license.

\begin{tabular}{|c|c|c|c|c|c|c|}
\hline GNS & $\begin{array}{l}\mathrm{N} \text {-acetylglucosamine-6- } \\
\text { sulfatase }\end{array}$ & P15586 & Membrane & -2.67 & 0.03261 & $\begin{array}{l}\text { Calcium binding (unclear role in exo- } \\
\text { cytosis) }\end{array}$ \\
\hline FGG & Fibrinogen gamma chain & P02679 & Cytosol & -2.69 & 0.01811 & Unclear role in exocytosis \\
\hline FGB & Fibrinogen beta chain & P02675 & Cytosol & -2.72 & 0.02085 & Unclear role in exocytosis \\
\hline CTSA & $\begin{array}{l}\text { Lysosomal protective } \\
\text { protein }\end{array}$ & P10619 & Cytosol & -2.73 & 0.04395 & $\begin{array}{l}\text { Lysosomal protease (unclear role in } \\
\text { exocytosis) }\end{array}$ \\
\hline HBB & Hemoglobin subunit beta & P68871 & Cytosol & -2.76 & 0.00349 & Unclear role in exocytosis \\
\hline METTL7A & $\begin{array}{l}\text { Methyltransferase-like } \\
\text { protein } 7 \mathrm{~A}\end{array}$ & Q9H8H3 & Membrane & -2.82 & 0.01175 & Unclear role in exocytosis \\
\hline APOOL & $\begin{array}{l}\text { MICOS complex subunit } \\
\text { MIC27 }\end{array}$ & Q6UXV4 & Membrane & -2.85 & 0.01445 & $\begin{array}{l}\text { Mitochondrial inner membrane (un- } \\
\text { clear role in exocytosis) }\end{array}$ \\
\hline DLD & $\begin{array}{l}\text { Dihydrolipoyl dehydroge- } \\
\text { nase, mitochondrial }\end{array}$ & P09622 & Cytosol & -2.87 & 0.00574 & Unclear role in exocytosis \\
\hline FGB & Fibrinogen beta chain & P02675 & Membrane & -2.93 & 0.01206 & Unclear role in exocytosis \\
\hline HSPD1 & $\begin{array}{l}60 \mathrm{kDa} \text { heat shock pro- } \\
\text { tein, mitochondrial }\end{array}$ & P10809 & Membrane & -2.93 & 0.00580 & $\begin{array}{l}\text { Protein folding, acrosomal exocy- } \\
\text { tosis }\end{array}$ \\
\hline ACAA1 & $\begin{array}{l}\text { 3-ketoacyl-CoA thiolase, } \\
\text { peroxisomal }\end{array}$ & P09110 & Membrane & -2.99 & 0.00305 & $\begin{array}{l}\text { Lipid metabolism, fatty acid metabo- } \\
\text { lism, insulin secretion }\end{array}$ \\
\hline STX7 & Syntaxin-7 & 015400 & Cytosol & -3.10 & 0.00905 & $\begin{array}{l}\text { Protein trafficking from plasma mem- } \\
\text { brane to endosomes, homotypic fu- } \\
\text { sion of endocytic organelles, endo- } \\
\text { cytosis, SNARE, SNARE binding, }\end{array}$ \\
\hline ITGA2B & Integrin alpha-Ilb & P08514 & Membrane & -3.17 & 0.00290 & Platelet degranulation \\
\hline CTSD & Cathepsin-D & P07339 & Membrane & -3.17 & 0.02030 & $\begin{array}{l}\text { Lysosomal protease (unclear role in } \\
\text { exocytosis) }\end{array}$ \\
\hline COMMD3 & $\begin{array}{l}\text { COMM domain-contai- } \\
\text { ning protein } 3\end{array}$ & Q9UBI1 & Cytosol & -3.19 & 0.00751 & Phosphoinositides regulation, lipids \\
\hline $\mathrm{F} 13 \mathrm{~A} 1$ & $\begin{array}{l}\text { Coagulation factor XIII A } \\
\text { chain }\end{array}$ & P00488 & Cytosol & -3.29 & 0.01539 & $\begin{array}{l}\text { Calcium binding, coagulation factor } \\
\text { (unclear role in exocytosis) }\end{array}$ \\
\hline PPBP & Platelet basic protein & P02775 & Cytosol & -3.31 & 0.00348 & $\begin{array}{l}\text { Stimulates formation and secretion } \\
\text { of plasminogen activator, secreted }\end{array}$ \\
\hline GLB1 & Beta-galactosidase & P16278 & Membrane & -3.32 & 0.01990 & Lipid organisation and metabolism \\
\hline PTGES2 & $\begin{array}{l}\text { Prostaglandin E syn- } \\
\text { thase } 2\end{array}$ & Q9H7Z7 & Membrane & -3.33 & 0.00219 & $\begin{array}{l}\text { Receptor coupled to G proteine Gi, } \\
\text { AMPc (unclear role in exocytosis) }\end{array}$ \\
\hline ANXA11 & Annexin A11 & P50995 & Membrane & -3.35 & 0.00743 & $\begin{array}{l}\text { Vesicular trafficking ER to golgi, cal- } \\
\text { cium binding, lipid binding }\end{array}$ \\
\hline SYPL1 & $\begin{array}{l}\text { Synaptophysin-like pro- } \\
\text { tein } 1\end{array}$ & Q16563 & Membrane & -3.36 & 0.00318 & $\begin{array}{l}\text { Syntaxin1 binding, SNARE binding, } \\
\text { VAMP2 binding, endocytosis }\end{array}$ \\
\hline CYBB & $\begin{array}{l}\text { Cytochrome b-245 } \\
\text { heavy chain }\end{array}$ & P04839 & Membrane & -3.40 & 0.00825 & $\begin{array}{l}\text { Regulation of cellular pH, ROS (un- } \\
\text { clear role in exocytosis) }\end{array}$ \\
\hline GLB1 & Beta-galactosidase & P16278 & Cytosol & -3.42 & 0.00759 & Lipid organisation and metabolism \\
\hline FN1 & Fibronectin & P02751 & Membrane & -3.42 & 0.00157 & $\begin{array}{l}\text { Cell adhesion, cell motility, opsoni- } \\
\text { zation, wound healing, maintenance } \\
\text { of cell shape, extracellular matrix } \\
\text { glycoprotein (unclear role in exocyto- } \\
\text { sis) }\end{array}$ \\
\hline FGG & Fibrinogen gamma chain & P02679 & Membrane & -3.50 & 0.00445 & Unclear role in exocytosis \\
\hline
\end{tabular}


bioRxiv preprint doi: https://doi.org/10.1101/2021.11.02.466874; this version posted November 5, 2021. The copyright holder for this preprint (which was not certified by peer review) is the author/funder, who has granted bioRxiv a license to display the preprint in perpetuity. It is made available under aCC-BY-NC-ND 4.0 International license.

SNCA Alpha-synuclein

P37840

Cytosol

$-3.54$

0.00338

\begin{tabular}{|ll} 
FLNA & Filamin-A \\
\hline CTSH & Pro-cathepsin H \\
CREG1 & $\begin{array}{l}\text { Protein CREG1 } \\
\text { Coagulation factor XIII A } \\
\text { chain }\end{array}$ \\
ACAA1 & $\begin{array}{l}\text { 3-ketoacyl-CoA thiolase } \\
\text { peroxisomal }\end{array}$ \\
\hline
\end{tabular}

P21333

Cytosol

$-3.60$

0.00118

P09668

Cytosol

$-3.62$

0.00312

075629

Cytosol

$-3.63$

0.00275

P00488

Membrane

$-3.79$

0.00168

P09110

Cytosol

$-3.94$

0.00584

FLNA Filamin-A

P21333

Membrane

$-4.09$

0.00175

DGAT1 $\begin{aligned} & \text { Diacylglycerol O-acyl- } \\ & \text { transferase } 1\end{aligned}$

IQGAP2

Ras GTPase-activating-

like protein IQGAP2

075907

Membrane

$-4.26$

0.00164

IQGAP2

\begin{tabular}{ll|cccc} 
CD109 & CD109 antigen & Q6YHK3 & Cytosol & -4.64 & 0.00175 \\
\hline CAT & Catalase & P04040 & Cytosol & -4.74 & 0.00053
\end{tabular}

\begin{tabular}{|llllll} 
IDH1 & $\begin{array}{l}\text { Isocitrate deshydroge- } \\
\text { nase }\end{array}$ & O75874 & Membrane & -4.82 & 0.00136 \\
FERMT3 & $\begin{array}{l}\text { Fermitin family homolog } \\
3\end{array}$ & Q86UX7 & Cytosol & -5.00 & 0.00064
\end{tabular}

\begin{tabular}{|ll|cccc|} 
CYB5R3 & $\begin{array}{l}\text { NADH-cytochrome b5 } \\
\text { reductase 3 }\end{array}$ & P00387 & Cytosol & -5.02 & 0.00051 \\
\hline PPBP & Platelet basic protein & P02775 & Membrane & -5.33 & 0.00136 \\
\hline
\end{tabular}

IDH1 Isocitrate deshydroge-
nase

\begin{tabular}{|c|c|c|c|c|c|c|}
\hline SCCPDH & $\begin{array}{l}\text { Saccharopine dehydro- } \\
\text { genase-like oxidore- } \\
\text { ductase }\end{array}$ & Q8NBX0 & Cytosol & -6.09 & 0.00034 & Unclear role in exocytosis \\
\hline CAT & Catalase & P04040 & Membrane & -6.20 & 0.00049 & $\begin{array}{l}\text { Antioxidant enzyme (unclear role in } \\
\text { exocytosis) }\end{array}$ \\
\hline BST2 & $\begin{array}{l}\text { Bone marrow stromal } \\
\text { antigen } 2\end{array}$ & Q10589 & Membrane & -6.81 & 0.00050 & Actin cytoskeleton organization \\
\hline HSPD1 & $\begin{array}{l}60 \mathrm{kDa} \text { heat shock pro- } \\
\text { tein, mitochondrial }\end{array}$ & P10809 & Cytosol & -7.05 & 0.00060 & $\begin{array}{l}\text { Protein folding, acrosomal exocy- } \\
\text { tosis }\end{array}$ \\
\hline COL1A1 & $\begin{array}{l}\text { Collagen alpha-1(I) } \\
\text { chain }\end{array}$ & P02452 & Membrane & -9.00 & 0.00050 & $\begin{array}{l}\text { Extracellular matrix (unclear role in } \\
\text { exocytosis) }\end{array}$ \\
\hline PROS1 & $\begin{array}{l}\text { Vitamin K-dependent } \\
\text { protein S }\end{array}$ & P07225 & Cytosol & -10.73 & 0.00266 & $\begin{array}{l}\text { Calcium binding (unclear role in exo } \\
\text { cytosis) }\end{array}$ \\
\hline
\end{tabular}
fusion, dilation of fusion pores, calcium regulation, SNAREs assembly

Actin filament branching, cytoskeletal regulation, scaffold protein, exocyst

Lysosomal protease (unclear role in exocytosis)

Control of cell growth and differenciation, secreted

Calcium binding, coagulation factor (unclear role in exocytosis)

Lipid metabolism, fatty acid metabolism, insulin secretion

Actin filament branching, cytoskeletal regulation, scaffold protein, exocyst

Triacylglycerol synthesis, DAG pathway, lipid organization

Binds to activated Cdc42 and Rac1, associate with calmodulin, cytoskeleton regulation, exocyst complex, endocytosis

Modulates negatively TGFB1 signaling in keratinocytes (unclear role in exocytosis)

Antioxidant enzyme (unclear role in exocytosis)

Catalytic activity, phospholipid biosynthetic and catalytic process, insulin secretion

Cell adhesion (unclear role in exocytosis)

Lipid organisation, cholesterol biosynthesis (unclear role in exocytosis)

Stimulates formation and secretion of plasminogen activator, secreted Catalytic activity, phospholipid biosynthetic and catalytic process, insulin secretion

$\begin{array}{lllll}075874 & \text { Cytosol } & -5.64 & 0.00051 & \begin{array}{l}\text { synthetic and } \\ \text { lin secretion }\end{array}\end{array}$

Synaptic vesicle trafficking, priming, 
List of proteins involved in exocytosis detected by mass spectrometry in cytosol-and membraneenriched fractions. The median value of the fold change is obtained by comparing the expression from 5 pairs of tumor matched to non-tumor tissues. DAG: diacylglycerol, DCV: dense-core vesicle, ER: endoplasmic reticulum, FGF-1: fibroblast growth factor 1, GM1: monosialotetrahexosylganglioside, MAPK: mitogen-activated protein kinase, NSF: N-ethylmaleimide-Sensitive Factor, PKC: protein kinase C, PLC: phospholipase C, SNARE: soluble N-ethylmaleimide sensitive factor attachment receptor, ROS: reactive oxygen species, TGFB1: transforming growth factor beta 1, TGN: trans-Golgi network. 